\title{
Biological Evaluation of DNA Biomarkers in a Chemically Defined and Site-Specific Manner
}

\author{
Ke Bian ${ }^{1}{ }^{\oplus}$, James C. Delaney ${ }^{2}$, Xianhao Zhou ${ }^{1}$ and Deyu Li ${ }^{1, *}$ \\ 1 Department of Biomedical and Pharmaceutical Sciences, College of Pharmacy, University of Rhode Island, \\ Kingston, RI 02881, USA; kebian@uri.edu (K.B.); xianhao_zhou@my.uri.edu (X.Z.) \\ 2 Visterra, Inc., 275 Second Avenue, Waltham, MA 02451, USA; delaney@mit.edu \\ * Correspondence: deyuli@uri.edu; Tel.: +1-(401)-874-9361
}

Received: 25 May 2019; Accepted: 14 June 2019; Published: 25 June 2019

\begin{abstract}
As described elsewhere in this Special Issue on biomarkers, much progress has been made in the detection of modified DNA within organisms at endogenous and exogenous levels of exposure to chemical species, including putative carcinogens and chemotherapeutic agents. Advances in the detection of damaged or unnatural bases have been able to provide correlations to support or refute hypotheses between the level of exposure to oxidative, alkylative, and other stresses, and the resulting DNA damage (lesion formation). However, such stresses can form a plethora of modified nucleobases, and it is therefore difficult to determine the individual contribution of a particular modification to alter a cell's genetic fate, as measured in the form of toxicity by stalled replication past the damage, by subsequent mutation, and by lesion repair. Chemical incorporation of a modification at a specific site within a vector (site-specific mutagenesis) has been a useful tool to deconvolute what types of damage quantified in biologically relevant systems may lead to toxicity and/or mutagenicity, thereby allowing researchers to focus on the most relevant biomarkers that may impact human health. Here, we will review a sampling of the DNA modifications that have been studied by shuttle vector techniques.
\end{abstract}

Keywords: DNA lesion; DNA damage; shuttle vector technique; replication block; mutagenicity; mutational spectrum; mutational signature; DNA repair; DNA adduct bypass; site-specific mutagenesis

\section{Introduction}

The human genome is constantly exposed to and damaged by endogenous chemicals, such as reactive oxygen species, lipid peroxidation intermediates, and alkylating agents. These electrophilic reactive chemicals, as well as environmental carcinogens and administered drugs, are known to generate various DNA adducts [1-3]. Some of the adducts block DNA replication or cause mutations and have been used as biomarkers to monitor the level of DNA damage or of disease progression [4-6]. One of the major goals for researchers is to understand the deleterious consequences of those lesions within the cell or animal. Among the different methods for studying the biological effects of the adducts, use of shuttle vectors containing a chemically defined lesion at a specific site has provided information about the biological and toxicological properties of the adduct $[4,7]$. The shuttle vector-based methods normally involve the steps outlined in Figure 1. Oligonucleotide synthesis: An oligonucleotide (oligo) containing a structurally defined lesion at a specific site is made either through a biomimetic route (in situ formation by direct chemical reaction, followed by HPLC purification of site-specifically modified oligo), or purely synthetically using a normal or convertible nucleoside phosphoramidite, etc. Vector construction: An ss- or ds-DNA vector containing the modified oligo is built by cutting the parent vector with one or a pair of restriction endonuclease(s), followed by ligation of the 5'-phosphorylated modified oligo. Cellular processing: The vector is transfected into different types of cells (e.g., Escherichia. coli (E. coli) or mammalian), and cellular polymerases are allowed 
to replicate or transcriptionally bypass the lesion under different repair or bypass conditions. Data analysis: DNA is extracted, amplified using PCR, and the biological outcomes are analyzed, which include the ability of the lesion/adduct to block polymerases or cause a mutation when processed by a polymerase during cellular replication. This assessment could be done by plaque or colony counting and picking with Sanger sequencing, ${ }^{32} \mathrm{P}$-post labeling and thin-layer chromatography (TLC), liquid chromatography-mass spectrometry (LC-MS), next-generation sequencing (NGS), etc. [4,5,7-9]. The shuttle vector-based method was initially introduced by Essigmann [7,9-11], further developed and utilized by Wang [4,5], Moriya [12,13], Livneh [14,15], Greenberg [16,17], Basu [18,19], Lloyd [20,21], Loechler [22,23], Fuchs [24,25], Pagès [26,27], and others. Several informative review articles have been written by these authors on designing and applying the methods.

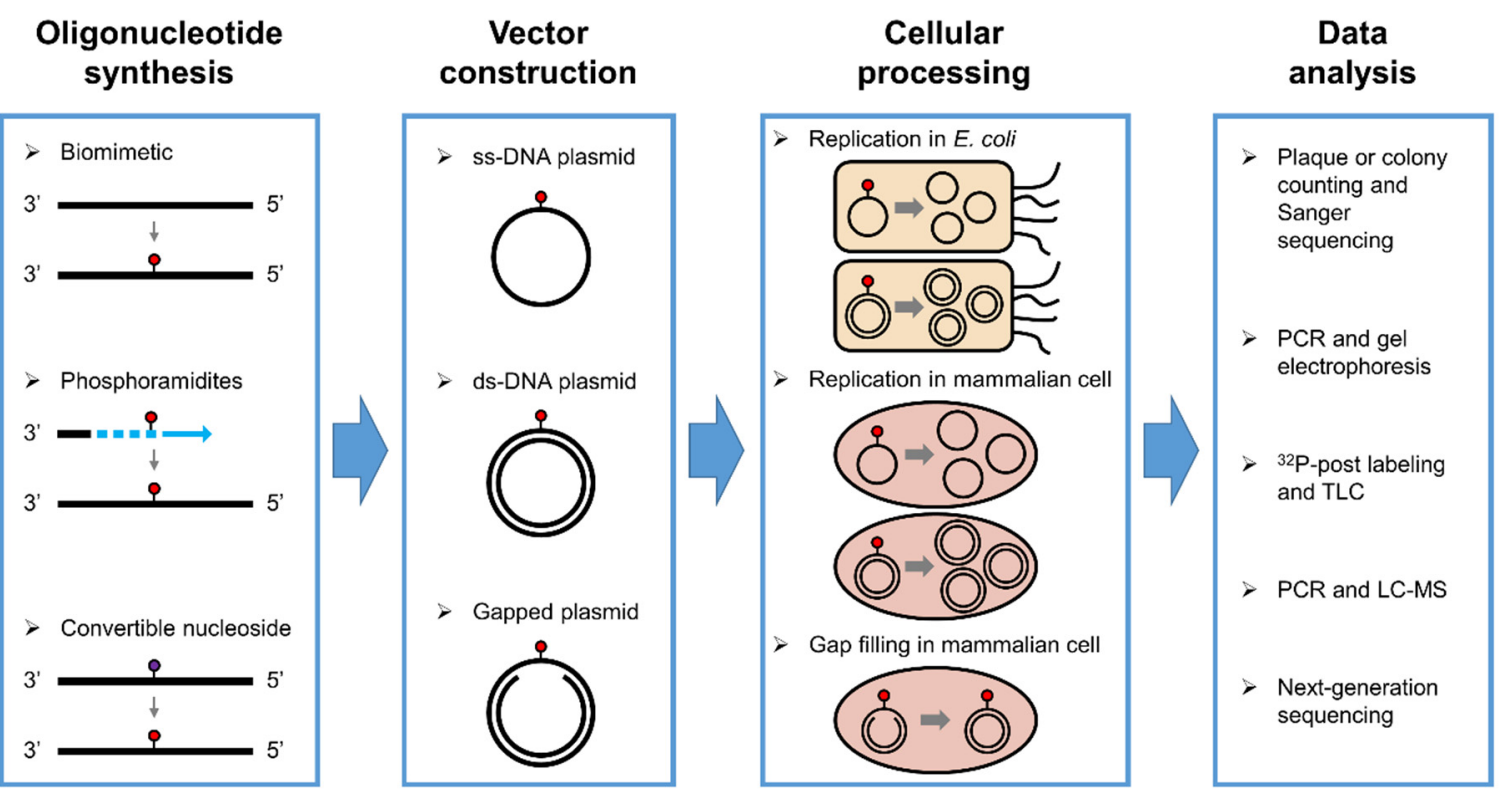

Figure 1. Schematic overview of the shuttle vector-based methods for evaluating DNA biomarkers.

In this work, we will review a variety of DNA biomarkers or probes that have been studied using the shuttle vector techniques and briefly summarize their biological outcomes. In all cases, focus is placed on the effect of the lesion to block replication and to cause mutations. For the details regarding the formation of DNA damage and other properties of the lesions, please refer to the original literature or review articles. We apologize in advance to researchers whose work we could not include in this review. After detailed discussions on individual lesions, we will provide some perspectives on possible future directions.

\section{Discussions on Individual Modifications}

Below, we will cover modified DNA structures generated from oxidative stress, alkylation, and other processes (Figures 2-5). In the following sections, the biological effects of a certain lesion are briefly summarized. Please see Figures 2-5 for chemical structures and Table 1 for detailed information. 
Table 1. Bypass efficiency and mutagenicity of DNA modifications.

\begin{tabular}{|c|c|c|c|}
\hline Oxidative Lesion & Bypass Efficiency & Mutation & Cell \\
\hline \multirow{2}{*}{ 8-oxo-G } & $88 \%[28,29]$ & G>T 3\% (44\%, MutY-) $[28,29]$ & E. coli \\
\hline & & $\mathrm{G}>\mathrm{T} 8 \%[30]$ & Human \\
\hline \multirow{2}{*}{ Fapy-dG } & $31-43 \%$ (TXN sequences) [31] & G>T 1.2-1.9\% (0.7-2.1\%, MutM-/MutY-) [31] & E. coli \\
\hline & & $\mathrm{G}>\mathrm{T} 10 \%[30]$ & Human \\
\hline NI & $7 \%(57 \%$, SOS) $[32]$ & $\begin{array}{c}\mathrm{G}>\mathrm{C} 8.9 \%, \mathrm{G}>\mathrm{A} 19 \%, \mathrm{G}>\mathrm{T} 22 \%(\mathrm{G}>\mathrm{C} 2.5 \%, \mathrm{G}>\mathrm{A} \\
13 \%, \mathrm{G}>\mathrm{T}, 18 \%, \mathrm{SOS})[32]\end{array}$ & E. coli \\
\hline $\mathrm{Oa}$ & $\begin{array}{l}52 \%[28], 51 \%[33], 108 \%(118 \% \\
\text { MutY-) [29] }\end{array}$ & $\begin{array}{c}\mathrm{G}>\mathrm{T} 97 \%[28], 99 \% \text { [33], } 97 \% \text { (no change, MutY-) } \\
\text { [29] }\end{array}$ & E. coli \\
\hline $\mathrm{Oz}$ & $57 \%[28]$ & $\mathrm{G}>\mathrm{T} 86 \%[28]$ & E. coli \\
\hline $\mathrm{Ca}$ & $65 \%[28]$ & G>T 95\% [28] & E. coli \\
\hline Gh & $75 \%$ [34], 20\% (30\% MutY-) [29] & $\begin{array}{c}\mathrm{G}>\mathrm{C} 98 \%, \mathrm{G}>\mathrm{T} 2 \%[34], \mathrm{G}>\mathrm{T} 40 \%, \mathrm{G}>\mathrm{C} 57 \%, \mathrm{G}>\mathrm{A} \\
3 \% \text { (no change, MutY-) [29] }\end{array}$ & E. coli \\
\hline Sp1 & $9 \%[34], 19 \%$ (38\%, MutY-) [29] & $\begin{array}{c}\mathrm{G}>\mathrm{C} 72 \%, \mathrm{G}>\mathrm{T} 27 \%[34], \mathrm{G}>\mathrm{T} 78 \%, \mathrm{G}>\mathrm{C} 19 \%, \mathrm{G}>\mathrm{A} \\
1 \% \text { (no change, MutY-) [29] }\end{array}$ & E. coli \\
\hline Sp2 & $9 \%[34], 17 \%(30 \%$, MutY-) [29] & $\begin{array}{c}\mathrm{G}>\mathrm{C} 57 \%, \mathrm{G}>\mathrm{T} 41 \%[34], \mathrm{G}>\mathrm{T} 49 \%, \mathrm{G}>\mathrm{C} 48 \%, \mathrm{G}>\mathrm{A} \\
3 \% \text { (no change, MutY-) [29] }\end{array}$ & E. coli \\
\hline Ur & $11 \%$ [35], 10\% (10\% MutY-) [29] & $\begin{array}{c}\mathrm{G}>\mathrm{T} 99 \%[35], \mathrm{G}>\mathrm{T} 54 \%, \mathrm{G}>\mathrm{C} 35 \%, \mathrm{G}>\mathrm{A} 9 \% \text { (no } \\
\text { change, MutY-) [29] }\end{array}$ & E. coli \\
\hline $\mathrm{Iz}$ & $60 \%(71 \%, \mathrm{SOS})[32]$ & $\begin{array}{c}\mathrm{G}>\mathrm{C} 88 \%, \mathrm{G}>\mathrm{A} 2 \%, \mathrm{G}>\mathrm{T} 1.1 \%(\mathrm{G}>\mathrm{C} 75 \%, \mathrm{G}>\mathrm{A} \\
3.4 \%, \mathrm{G}>\mathrm{T} 5.5 \%, \mathrm{SOS})[32]\end{array}$ & E. coli \\
\hline Cyclo-dG & $11 \%(6 \%$ pol V-) $[36]$ & $\mathrm{G}>\mathrm{A} 20 \%[36]$ & E.coli \\
\hline S-cdG & $4 \%[37]$ & $\mathrm{G}>\mathrm{T} 35 \%, \mathrm{G}>\mathrm{A} 20 \%$ [37] & Human \\
\hline Cyclo-dA & $31 \%(13 \%$ pol V-) [36] & $\mathrm{A}>\mathrm{T} 11 \%[36]$ & E. coli \\
\hline S-cdA & $6 \%[37]$ & $\mathrm{A}>\mathrm{T} 12 \%[37]$ & Human \\
\hline $\mathrm{Tg}$ & $96 \%[38]$ & & E. coli \\
\hline $5 \mathrm{ClC}$ & 75\% (75\% AlkB-) [39] & C>T 5\% (same in AlkB-) [39] & E. coli \\
\hline $5-\mathrm{OH}-\mathrm{C}$ & & $\mathrm{C}>\mathrm{T} 0.05 \%, \mathrm{C}>\mathrm{G} 0.001 \%[40]$ & E. coli \\
\hline $5-\mathrm{OH}-\mathrm{U}$ & & $\mathrm{C}>\mathrm{T} 83 \%[40]$ & E. coli \\
\hline $\mathrm{Ug}$ & & $\mathrm{C}>\mathrm{T} 80 \%[40]$ & E. coli \\
\hline THF AP site & $\begin{array}{l}6 \%[28], 5.8 \%[32], 4 \%(4 \% \\
\text { MutY-) [29] }\end{array}$ & $\begin{array}{c}\mathrm{AP}>\mathrm{T} 50 \%, \mathrm{AP}>\mathrm{C} 26 \%, \mathrm{AP}>\mathrm{A} 7 \%,-1 \text { del } 13 \% \text { (no } \\
\text { change, MutY-) [29] }\end{array}$ & E. coli \\
\hline 2-deoxyribonolactone & $5 \%,(3 \%$ pol II- $),(1 \%$ pol V-) $[41]$ & $\begin{array}{c}\text { T } 35 \%, \text { C } 42 \%, \text { A } 12 \%, \text { G } 8 \%, 5^{\prime} \text { T (T } 42 \%, \text { C } 38 \%, \text { A } \\
6 \%, \text { G } 14 \%, 5^{\prime} \text { C) [41] }\end{array}$ & E. coli \\
\hline Alkyl Modification & Bypass Efficiency & Mutation & Cell \\
\hline $\mathrm{m} 1 \mathrm{G}$ & $\begin{array}{c}15 \%(3 \%, \text { AlkB-) [9], 20\% (2\%, } \\
\text { AlkB-) [33] }\end{array}$ & $\begin{array}{c}\mathrm{G}>\mathrm{T} 3 \%(\mathrm{G}>\mathrm{T} 57 \%, \mathrm{G}>\mathrm{A} 17 \%, \mathrm{G}>\mathrm{C} 6 \%, \mathrm{AlkB}-)[9] \\
\mathrm{G}>\mathrm{T} 4 \%, \mathrm{G}>\mathrm{A} 2 \%(\mathrm{G}>\mathrm{T} 52 \%, \mathrm{G}>\mathrm{A} 20 \%, \mathrm{G}>\mathrm{C} 4 \% \\
\text { AlkB- })[33]\end{array}$ & E. coli \\
\hline $\mathrm{m} 2 \mathrm{G}$ & $\begin{array}{c}\text { 90\% (84\% AlkB-; } 98 \% \text { DinB-; } 96 \% \\
\text { AlkB- and DinB-) [42] }\end{array}$ & $\begin{array}{c}\text { G>A 3\% (2.7\%, AlkB-; 3\%, DinB-; 3\%, AlkB- and } \\
\text { DinB-) [42] }\end{array}$ & E. coli \\
\hline e2G & $\begin{array}{c}100 \% \text { (98\% AlkB-), (106\% DinB-) } \\
\text { (99\% AlkB- and DinB-) [42] }\end{array}$ & $\begin{array}{c}\mathrm{G}>\mathrm{A} 2 \%, \mathrm{G}>\mathrm{C} 1 \%(\mathrm{G}>\mathrm{A} 2.3 \%, \text { AlkB- }),(\mathrm{G}>\mathrm{A} 2 \%, \\
\text { AlkB- and DinB-) [42] }\end{array}$ & E. coli \\
\hline$N^{2}-\mathrm{CMdG}$ & $100 \%[43]$ & Not mutagenic [43] & Mouse \\
\hline \multirow{2}{*}{$\mathrm{R}-N^{2}-\mathrm{CEdG}$} & $39 \%(13 \%$ pol V-) [44] & Not mutagenic [44] & E. coli \\
\hline & $100 \%[43]$ & Not mutagenic (G>A 23\%, G>T 15\%, pol k-) [43] & Mouse \\
\hline \multirow{2}{*}{$\mathrm{S}-N^{2}-\mathrm{CEdG}$} & $75 \%(28 \%$ pol V-) $[44]$ & Not mutagenic [44] & E. coli \\
\hline & $99 \%[43]$ & Not mutagenic (G>A 23\%, G>T 15\%, pol k-) [43] & Mouse \\
\hline FF & $\begin{array}{c}101 \% \text { (100\% AlkB-), (28\% DinB-) } \\
\text { (36\% AlkB- and DinB-) [42] }\end{array}$ & G>C 1\%, (G>A 1\%, G>T 1\%, AlkB-DinB-) [42] & E. coli \\
\hline $\mathrm{HF}$ & $\begin{array}{l}92 \%(88 \% \text { AlkB-), (28\% DinB-), } \\
\text { (40\% AlkB- and DinB-) [42] }\end{array}$ & $\mathrm{G}>\mathrm{C} 2 \%[42]$ & E. coli \\
\hline $\mathrm{O}^{6} \mathrm{mG}$ & & G>A $99 \%[45,46]$ & E. coli \\
\hline $\mathrm{O}^{6}$-POB-dG & $70 \%$ [47] & $\mathrm{G}>\mathrm{A} 90 \%, \mathrm{G}>\mathrm{T} 2.5 \%[47]$ & E. coli \\
\hline $\mathrm{O}^{6}$-PHB-dG & $40 \%[47]$ & G>A 95\% [47] & E. coli \\
\hline \multirow{2}{*}{$\mathrm{O}^{6}-\mathrm{CM}-\mathrm{dG}$} & $10 \%[47]$ & $\mathrm{G}>\mathrm{A} 10 \%[47]$ & E. coli \\
\hline & $40 \%[48]$ & $\mathrm{G}>\mathrm{A} 6 \%[48]$ & Human \\
\hline $\mathrm{O}^{6}-\mathrm{ACM}-\mathrm{dG}$ & $2 \%[47]$ & $\mathrm{G}>\mathrm{A} 30 \%[47]$ & E. coli \\
\hline
\end{tabular}


Table 1. Cont

\begin{tabular}{|c|c|c|c|}
\hline Alkyl Modification & Bypass Efficiency & Mutation & Cell \\
\hline $\mathrm{O}^{6}$-HOEt-dG & $15 \%[47]$ & $\mathrm{G}>\mathrm{A} 40 \%[47]$ & E. coli \\
\hline PdG & $25 \%[12]$ & $\mathrm{G}>\mathrm{T} 6 \%[12]$ & Human \\
\hline$\alpha-\mathrm{OH}-\mathrm{PdG}$ & $17 \%[12]$ & $\mathrm{G}>\mathrm{T} 11 \%[12]$ & Human \\
\hline$\gamma$-OH-PdG & $73 \%$ [12] & Not mutagenic [12] & Human \\
\hline $1, N^{2}-\mathrm{eG}$ & $\begin{array}{l}4 \% \text { (2\% AlkB-) }(1.8 \% \\
\text { AlkB-DinB-) }[8]\end{array}$ & $\begin{array}{c}\mathrm{G}>\mathrm{A} 6 \%, \mathrm{G}>\mathrm{T} 6 \%, \mathrm{G}>\mathrm{C} 2 \%,-1 / 2 \text { del } 5 \%(\mathrm{G}>\mathrm{A} 13 \% \\
\mathrm{G}>\mathrm{T} 13 \%, \mathrm{G}>\mathrm{C} 1 \%,-1 / 2 \text { del } 9 \%, \text { AlkB-), (same in } \\
\text { AlkB-DinB-) [8] }\end{array}$ & E. coli \\
\hline $2^{\prime}-\mathrm{F}-N^{2}, 3-\mathrm{eG}$ & $\begin{array}{l}21 \% \text { (26\% AlkB-) }(14 \% \\
\text { AlkB-DinB-) [8] }\end{array}$ & G>A 30\% (30\% AlkB-), (30\% AlkB-DinB-) [8] & E. coli \\
\hline $\mathrm{m} 1 \mathrm{~A}$ & $100 \%(12 \%$, AlkB- $)[9]$ & $\mathrm{A}>\mathrm{T} 0.06 \%(0.61 \%$, AlkB- $)[9]$ & E. coli \\
\hline \multirow[t]{2}{*}{ eA } & $\begin{array}{c}85 \% \text { (5\% AlkB-) [33], } 130 \%(9 \% \\
\text { AlkB-) [49] }\end{array}$ & $\begin{array}{c}<0.5 \%(\mathrm{~A}>\mathrm{T} 25 \%, \mathrm{~A}>\mathrm{G} 5 \%, \mathrm{~A}>\mathrm{C} 5 \%, \mathrm{AlkB}-)[33], \\
\mathrm{A}>\mathrm{C} 1 \%, \mathrm{~A}>\mathrm{T} 1 \%(\mathrm{~A}>\mathrm{T} 22 \%, \mathrm{~A}>\mathrm{C} 8 \%, \mathrm{~A}>\mathrm{G} 7 \%, \\
\text { AlkB-) [49] }\end{array}$ & E. coli \\
\hline & $17 \%[50]$ & & Human \\
\hline EA & 135\% (14\% AlkB-) [49] & $\begin{array}{c}\mathrm{A}>\mathrm{C} 1 \%, \mathrm{~A}>\mathrm{G} 0.5 \%, \mathrm{~A}>\mathrm{T} 0.5 \%(\mathrm{~A}>\mathrm{C} 2 \%, \mathrm{~A}>\mathrm{G} 1 \%, \\
\mathrm{A}>\mathrm{T} 1 \%, \mathrm{AlkB}-\mathrm{C}^{[49]}\end{array}$ & E. coli \\
\hline \multirow{2}{*}{$N^{6}-\mathrm{CMdA}$} & $98 \%[36]$ & Not mutagenic [36] & E. coli \\
\hline & $65 \%$ (35\% pol k-) [48] & Not mutagenic [48] & Human \\
\hline$S-N^{6}-\mathrm{HB}-\mathrm{dA}$ & $120 \%[51]$ & Not mutagenic [51] & E. coli \\
\hline$R, R-N^{6}, N^{6}$-DHB-dA & $100 \%[51]$ & $<1 \%[51]$ & E. coli \\
\hline$S, S-N^{6}, N^{6}-\mathrm{DHB}-\mathrm{dA}$ & $60 \%[51]$ & $\mathrm{A}>\mathrm{G} 1 \%[51]$ & E. coli \\
\hline$R, S-1, N^{6}-\gamma$-HMHP-dA & $10 \%[51]$ & $\mathrm{A}>\mathrm{T} 2 \%[51]$ & E. coli \\
\hline \multirow{2}{*}{$\mathrm{O}^{2}$-MedT } & $60 \%[52], 55 \%[53]$ & $\mathrm{T}>\mathrm{A} 1 \%, \mathrm{~T}>\mathrm{G} 1 \%[52], \mathrm{T}>\mathrm{A} 56 \%[53]$ & Human \\
\hline & $5 \%[54]$ & $\mathrm{T}>\mathrm{A} 10 \%, \mathrm{~T}>\mathrm{G} 10 \%[54]$ & E. coli \\
\hline \multirow{2}{*}{$\mathrm{O}^{2}$-EtdT } & $21 \%(5 \%$ pol V-) [55] & $\mathrm{T}>\mathrm{C} 35 \%, \mathrm{~T}>\mathrm{A} 15 \%, \mathrm{~T}>\mathrm{G} 5 \%(\mathrm{~T}>\mathrm{C} 10 \%, \mathrm{pol} \mathrm{V}-)$ & E. coli \\
\hline & $45 \%[52]$ & $\mathrm{T}>\mathrm{A} 5 \%, \mathrm{~T}>\mathrm{G} 3 \%[52]$ & Human \\
\hline$O^{2}-n \operatorname{PrdT}$ & $35 \%[52]$ & $\mathrm{T}>\mathrm{A} 12 \%, \mathrm{~T}>\mathrm{G} 5 \%[52]$ & Human \\
\hline $\mathrm{O}^{2}-i \operatorname{PrdT}$ & $35 \%[52]$ & $\mathrm{T}>\mathrm{A} 4 \%, \mathrm{~T}>\mathrm{G} 1 \%[52]$ & Human \\
\hline $\mathrm{O}^{2}-n \mathrm{BudT}$ & $30 \%[52]$ & $\mathrm{T}>\mathrm{A} 13 \%, \mathrm{~T}>\mathrm{G} 6 \%[52]$ & Human \\
\hline $\mathrm{O}^{2}-\mathrm{B}$ BudT & $15 \%[52]$ & $\mathrm{T}>\mathrm{A} 4 \%, \mathrm{~T}>\mathrm{G} 2 \%[52]$ & Human \\
\hline $\mathrm{O}^{2}$-sBudT & $15 \%[52]$ & $\mathrm{T}>\mathrm{A} 4 \%, \mathrm{~T}>\mathrm{G} 2 \%[52]$ & Human \\
\hline \multirow{2}{*}{$\mathrm{O}^{2}$-POB-dT } & $3 \%[54]$ & $12 \% \mathrm{~T}>\mathrm{A}, 38 \% \mathrm{~T}>\mathrm{G}[54]$ & E. coli \\
\hline & $26 \%[53]$ & $\mathrm{T}>\mathrm{A} 47 \%[53]$ & Human \\
\hline $\mathrm{m} 3 \mathrm{~T}$ & $6 \%,(4 \%$ AlkB-) $[9]$ & $\begin{array}{c}\mathrm{T}>\mathrm{A} 32 \%, \mathrm{~T}>\mathrm{C} \text { 6\%, T>G 2\% (T>A 47\%, T>C 9\%, } \\
\text { T> }>\text { G 2\%, AlkB-) [9] }\end{array}$ & E. coli \\
\hline N3-EtdT & $17 \%(3 \%$ pol V-) [55] & $\begin{array}{c}\mathrm{T}>\mathrm{C} 15 \%, \mathrm{~T}>\mathrm{A} 21 \%, \mathrm{~T}>\mathrm{G} \mathrm{3} \% \text { (Not mutagenic, pol } \\
\mathrm{V} \text {-) [55] }\end{array}$ & E. coli \\
\hline \multirow{2}{*}{ N3-CMdT } & $55 \%[36]$ & $\mathrm{T}>\mathrm{A} 66 \%[36]$ & E. coli \\
\hline & $40 \%[48]$ & $\mathrm{T}>\mathrm{A} 81 \%[48]$ & Human \\
\hline \multirow{2}{*}{$\mathrm{O}^{4}$-CMdT } & $49 \%[36]$ & $\mathrm{T}>\mathrm{C} 86 \%[36]$ & E. coli \\
\hline & $40 \%[48]$ & $\mathrm{T}>\mathrm{C} 68 \%(25 \% \mathrm{pol} \zeta-)[48]$ & Human \\
\hline $\mathrm{O}^{4}$-MedT & $32 \%[56]$ & $\mathrm{T}>\mathrm{C} 58 \%[56]$ & Human \\
\hline \multirow{2}{*}{$\mathrm{O}^{4}$-EtdT } & $76 \%[55]$ & $\mathrm{T}>\mathrm{C} 84 \%$ (Not mutagenic, pol V-) [55] & E. coli \\
\hline & $33 \%[56]$ & $\mathrm{T}>\mathrm{C} 82 \%[56]$ & Human \\
\hline$O^{4}-n \operatorname{PrdT}$ & $35 \%[56]$ & $\mathrm{T}>\mathrm{C} 42 \%[56]$ & Human \\
\hline $\mathrm{O}^{4}-i \operatorname{PrdT}$ & $30 \%[56]$ & $\mathrm{T}>\mathrm{C} 44 \%[56]$ & Human \\
\hline$O^{4}-n$ BudT & $32 \%[56]$ & $\mathrm{T}>\mathrm{C} 29 \%[56]$ & Human \\
\hline $\mathrm{O}^{4}-\mathrm{iBudT}$ & $24 \%[56]$ & $\mathrm{T}>\mathrm{C} 42 \%[56]$ & Human \\
\hline $\mathrm{O}^{4}$-R-sBudT & $20 \%[56]$ & $\mathrm{T}>\mathrm{C} 25 \%[56]$ & Human \\
\hline $\mathrm{O}^{4}$-S-sBudT & $22 \%[56]$ & $\mathrm{T}>\mathrm{C} 25 \%[56]$ & Human \\
\hline $\mathrm{m} 3 \mathrm{C}$ & $\begin{array}{c}100 \% \text { (10\% AlkB-) [9], } 113 \% \text { (14\% } \\
\text { AlkB-) [57], 98\% (5\% AlkB-; } 115 \% \\
\text { DinB-; } 7.5 \% \text { AlkB-DinB-) [42] } \\
\text { 100\% (15\% AlkB-) [39] }\end{array}$ & 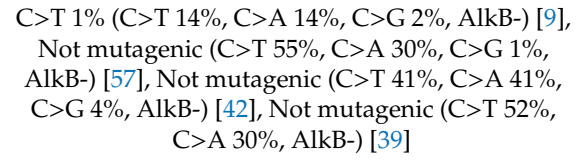 & E. coli \\
\hline
\end{tabular}


Table 1. Cont.

\begin{tabular}{|c|c|c|c|}
\hline Alkyl Modification & Bypass Efficiency & Mutation & Cell \\
\hline $\mathrm{e} 3 \mathrm{C}$ & 96\%, (9\% AlkB-) [9] & $\begin{array}{c}\text { Not mutagenic (C>T 17\%, C>A 11\%, C>G 2\%, } \\
\text { AlkB-) [9] }\end{array}$ & E. coli \\
\hline \multirow{2}{*}{$N^{4}-\mathrm{CMdC}$} & $83 \%[36]$ & Not mutagenic [36] & E. coli \\
\hline & $80 \%[48]$ & Not mutagenic [48] & Human \\
\hline \multirow{2}{*}{$5 \mathrm{mC}$} & $100 \%$ (100\% AlkB-) [39] & Not mutagenic (same in AlkB-) [39] & E. coli \\
\hline & $100 \%[58]$ & Not mutagenic [58] & Human \\
\hline \multirow{2}{*}{$5 \mathrm{hmC}$} & $100 \%[59]$ & Not mutagenic [59] & E. coli \\
\hline & $98 \%[58]$ & Not mutagenic [58] & Human \\
\hline \multirow{2}{*}{$5 \mathrm{fC}$} & $100 \%[59]$ & Not mutagenic [59] & E. coli \\
\hline & $74 \%[58]$ & Not mutagenic [58] & Human \\
\hline \multirow{2}{*}{$5 \mathrm{caC}$} & $100 \%[59]$ & Not mutagenic [59] & E. coli \\
\hline & $72 \%[58]$ & Not mutagenic [58] & Human \\
\hline $\mathrm{eC}$ & $24 \%$ (13\% AlkB-) [33] & $\begin{array}{c}\mathrm{C}>\mathrm{A} 24 \%, \mathrm{C}>\mathrm{T} 11 \%(\mathrm{C}>\mathrm{A} 49 \%, \mathrm{C}>\mathrm{T} 31 \%, \mathrm{AlkB}-) \\
{[33]}\end{array}$ & E. coli \\
\hline \multirow{2}{*}{ H-edC } & $1 \%[50]$ & $\mathrm{C}>\mathrm{G} 40 \%[50]$ & E. coli \\
\hline & $10 \%[50]$ & $\mathrm{C}>\mathrm{A} 60 \%, \mathrm{C}>\mathrm{T} 32 \%[50]$ & Human \\
\hline $5 \mathrm{hmU}$ & $80 \%[60]$ & Not mutagenic [60] & Human \\
\hline Sp-Me-PTE & $\begin{array}{l}110 \% \text { (Ada-, decreases from } \\
140 \% \text { to } 70 \% \text { ) [61] }\end{array}$ & TT>GT 50\%, TT>GC 15\% [61] & E. coli \\
\hline Rp-Me-PTE & $30 \%[61]$ & Not mutagenic [61] & E. coli \\
\hline Sp-Et-PTE & $190 \%[61]$ & Not mutagenic [61] & E. coli \\
\hline Rp-Et-PTE & $40 \%[61]$ & Not mutagenic [61] & E. coli \\
\hline Sp-nPr-PTE & $160 \%[61]$ & Not mutagenic [61] & E. coli \\
\hline Rp- $n$ Pr-PTE & $70 \%[61]$ & Not mutagenic [61] & E. coli \\
\hline Sp-nBu-PTE & $100 \%[61]$ & Not mutagenic [61] & E. coli \\
\hline Bulky Lesion & Bypass Efficiency & Mutation & Cell \\
\hline$N^{2}-\mathrm{MC}-\mathrm{dG}$ & $38 \%[62]$ & $\mathrm{G}>\mathrm{T} 18 \%[62]$ & Human \\
\hline$N^{2}-2,7-D A M-d G$ & $27 \%[62]$ & G>T 10\% [62] & Human \\
\hline AL-II-dG & $9 \%[63]$ & $\mathrm{G}>\mathrm{T} 9 \%[63]$ & Mouse \\
\hline $\mathrm{AFB}_{1}-\mathrm{N} 7-\mathrm{dG}$ & & $\mathrm{G}>\mathrm{T} 1.5 \%[64]$ & E. coli \\
\hline $\mathrm{AFB}_{1}$-FAPY & & $\mathrm{G}>\mathrm{T} 14 \%[65]$ & E. coli \\
\hline C8-AP-dG & $51 \%[66]$ & Not mutagenic [66] & Human \\
\hline C8-AAF-dG & $13 \%[66]$ & Not mutagenic [66] & Human \\
\hline C8-AF-dG & $97 \%[66]$ & Not mutagenic [66] & Human \\
\hline AL-I-dA & $100 \%$ (5\% Rev3L-) [67] & A>T 50\% (Not mutagenic, Rev3L-) [67] & Mouse \\
\hline AL-II-dA & $5 \%[63]$ & $\mathrm{A}>\mathrm{T} 22 \%[63]$ & Mouse \\
\hline BPDE-dG & (40\% Rev1-); (13\% Rev3L-) [68] & $\begin{array}{c}\mathrm{G}>\mathrm{T} 73 \%, \mathrm{G}>\mathrm{A} 12 \% ;(\mathrm{G}>\mathrm{T} 32 \%, \mathrm{G}>\mathrm{A} 18 \%, \operatorname{Rev1} 1) ; \\
\text { (G>T } 6 \% \text {, Rev3L-) [68] }\end{array}$ & Mouse \\
\hline Crosslinked Lesion & Bypass Efficiency & Mutation & Cell \\
\hline ICL-RD & $43 \%[69]$ & $5^{\prime}-\mathrm{G}>\mathrm{T} 3 \%[69]$ & E. coli \\
\hline ICL-R & $38 \%[69]$ & $5^{\prime}-\mathrm{G}>\mathrm{T} 3 \%[69]$ & E. coli \\
\hline ICL-S & $53 \%[69]$ & $5^{\prime}-\mathrm{G}>\mathrm{T} 3 \%[69]$ & E. coli \\
\hline AP-dG (dG strand) & 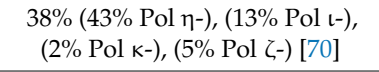 & G>A 2-5\%, G>T 1-2\%, G>C 1\% [70] & Human \\
\hline AP-dG (AP strand) & 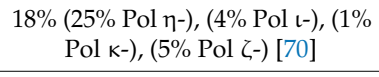 & $\begin{array}{c}\mathrm{AP}>\mathrm{T} 74 \%, \mathrm{AP}>\mathrm{C} 10-20 \%, \mathrm{AP}>\mathrm{G} 4-6 \%, \mathrm{AP}>\mathrm{A} \\
1-2 \%[70]\end{array}$ & Human \\
\hline 1,2-GG-cis-DDP & $11 \%$ [71]; $5 \%$ (30\% SOS) [72] & $<0.25 \%$ (G>T $1.3 \%$, SOS) [72] & E. coli \\
\hline 1,2-AG-cis-DDP & $22 \%(32 \% \mathrm{SOS})[72]$ & $<0.2 \%(\mathrm{~A}>\mathrm{T} 4.4 \%, \mathrm{SOS})[72]$ & E. coli \\
\hline 1,3-GTG-cis-DDP & $13 \%$ (14\% SOS) [72] & $<0.7 \%[72]$ & E. coli \\
\hline $\begin{array}{l}\gamma \text {-HOPdG mediated } \\
\text { peptide crosslink }\end{array}$ & & $\mathrm{G}>\mathrm{T} 5 \%, \mathrm{G}>\mathrm{C} 3 \%[20]$ & Human \\
\hline $\begin{array}{l}\gamma \text {-HOPdA mediated } \\
\text { peptide crosslink }\end{array}$ & & Not mutagenic [20] & Human \\
\hline $\begin{array}{l}5 \mathrm{fC} \text { mediated peptide } \\
\text { crosslink }\end{array}$ & & $\mathrm{C}>\mathrm{T} 7 \%, \mathrm{C}>\mathrm{G} 1 \%, \mathrm{C}$ del $2 \%[73]$ & Human \\
\hline
\end{tabular}


Table 1. Cont

\begin{tabular}{|c|c|c|c|}
\hline $\begin{array}{l}\text { Other Nucleotide } \\
\text { Analog }\end{array}$ & Bypass Efficiency & Mutation & Cell \\
\hline $\mathrm{H}$ & $5 \%[74]$ & $\mathrm{T}>\mathrm{A} 41 \%, \mathrm{~T}>\mathrm{C} 5 \%, \mathrm{~T}>\mathrm{G} 4 \%,-1 \mathrm{del} 13 \%[74]$ & E. coli \\
\hline F & $13 \%[74]$ & $\mathrm{T}>\mathrm{A} 9 \%, \mathrm{~T}>\mathrm{C} 1 \%, \mathrm{~T}>\mathrm{G} 1 \%[74]$ & E. coli \\
\hline $\mathrm{L}$ & $20 \%[74]$ & $\mathrm{T}>\mathrm{A} 5 \%[74]$ & E. coli \\
\hline B & $12 \%[74]$ & $\mathrm{T}>\mathrm{A} 24 \%[74]$ & E. coli \\
\hline I & $10 \%[74]$ & $\mathrm{T}>\mathrm{A} 46 \%, \mathrm{~T}>\mathrm{C} 1 \%, \mathrm{~T}>\mathrm{G} 1 \%,-1 \mathrm{del} 6 \%[74]$ & E. coli \\
\hline KP1212 & $128 \%[57]$ & $\mathrm{C}>\mathrm{T} 10 \%[57]$ & E. coli \\
\hline$x G$ & $11 \%$ (45\% SOS) [75] & G>A 95\% [75] & E. coli \\
\hline $\mathrm{xA}$ & $80 \%$ (108\% SOS) [75] & $<1 \%[75]$ & E. coli \\
\hline $\mathrm{xT}$ & $73 \%(102 \%$ SOS) [75] & $\mathrm{T}>\mathrm{A} 73 \%[75]$ & E. coli \\
\hline $\mathrm{xC}$ & $29 \%(53 \%$ SOS) [75] & $\mathrm{C}>\mathrm{A} 10 \%[75]$ & E. coli \\
\hline$\alpha-\mathrm{dG}$ & $3 \%[76]$ & $\mathrm{G}>\mathrm{A} 60 \%, \mathrm{G}>\mathrm{C} 6 \%[76]$ & E. coli \\
\hline$\alpha-\mathrm{dA}$ & $20 \%[76]$ & Not mutagenic [76] & E. coli \\
\hline$\alpha-\mathrm{dT}$ & $1 \%[76]$ & Not mutagenic [76] & E. coli \\
\hline$\alpha-\mathrm{dC}$ & $1 \%[76]$ & $\mathrm{C}>\mathrm{A} 72 \%[76]$ & E. coli \\
\hline $\mathrm{dxG}$ & $25 \%[77]$ & Not mutagenic [77] & E. coli \\
\hline $\mathrm{dxA}$ & $75 \%[77]$ & $\mathrm{A}>\mathrm{G} 10 \%[77]$ & E. coli \\
\hline $\mathrm{dxT}$ & $150 \%[77]$ & Not mutagenic [77] & E. coli \\
\hline $\mathrm{dxC}$ & $125 \%$ (CXT), 175\%(GXG) [77] & Not mutagenic [77] & E. coli \\
\hline \multirow{2}{*}{ sG } & $98 \%[78]$ & $\mathrm{G}>\mathrm{A} 11 \%[78]$ & E. coli \\
\hline & $98 \%$ [79] & G>A 8\% [79] & Human \\
\hline \multirow{2}{*}{$S^{6} \mathrm{mG}$} & $91 \%[78]$ & $\mathrm{G}>\mathrm{A} 94 \%[78]$ & E. coli \\
\hline & $95 \%$ [79] & $\mathrm{G}>\mathrm{A} 40 \%$ [79] & Human \\
\hline $\mathrm{SO}_{3} \mathrm{HG}$ & $87 \%[78]$ & $\mathrm{G}>\mathrm{A} 77 \%[78]$ & E. coli \\
\hline $2^{\prime}-\mathrm{F}-\mathrm{G}$ & $99 \%[8]$ & Not mutagenic [8] & E. coli \\
\hline $\mathrm{J}$ & $52 \%[60]$ & Not mutagenic [60] & Human \\
\hline
\end{tabular}<smiles>Cn1c(=O)[nH]c2c(=O)[nH]c(N)nc21</smiles>

$$
d R
$$

8-Oxo-G

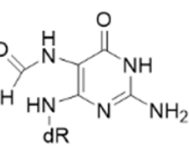

Fapy-dG
dR

NI
$\overbrace{\mathrm{HN}}^{\mathrm{O}} \mathrm{CO}_{\mathrm{O}}$

dR

Oa

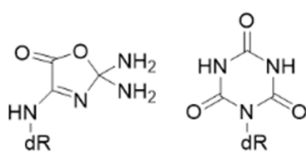

$\mathrm{Oz}$

$\mathrm{Ca}$<smiles>[R17]C1NC(=O)C(=O)NC1=O</smiles>
Sp1

- ${\underset{\mathrm{dR}}{\mathrm{dH}}}_{\mathrm{dR}}^{\mathrm{NH}_{2}}$

Iz

Ur<smiles>CCCn1cc(Cl)c(N)nc1=O</smiles>

$\overbrace{n}^{2}$

Sp2

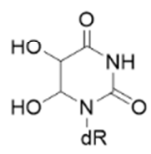

$\overbrace{N^{\prime}}^{\mathrm{NH}}$<smiles>[2H]C1CC(O)C(COC)O1</smiles>

5-Cl-C

5-OH-C

5-OH-U

Ug

$\mathrm{Tg}$

$\mathrm{R}=\mathrm{OH}$ AP site

$\mathrm{R}=\mathrm{H}$ THF

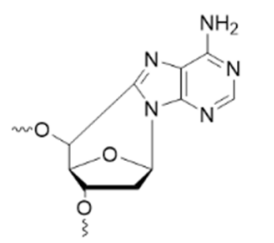

cdA

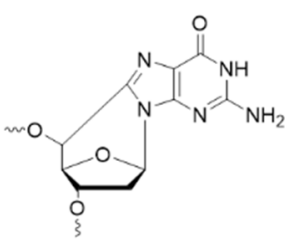

cdG

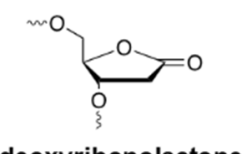

2-deoxyribonolactone

Figure 2. Structures of oxidative lesions. 

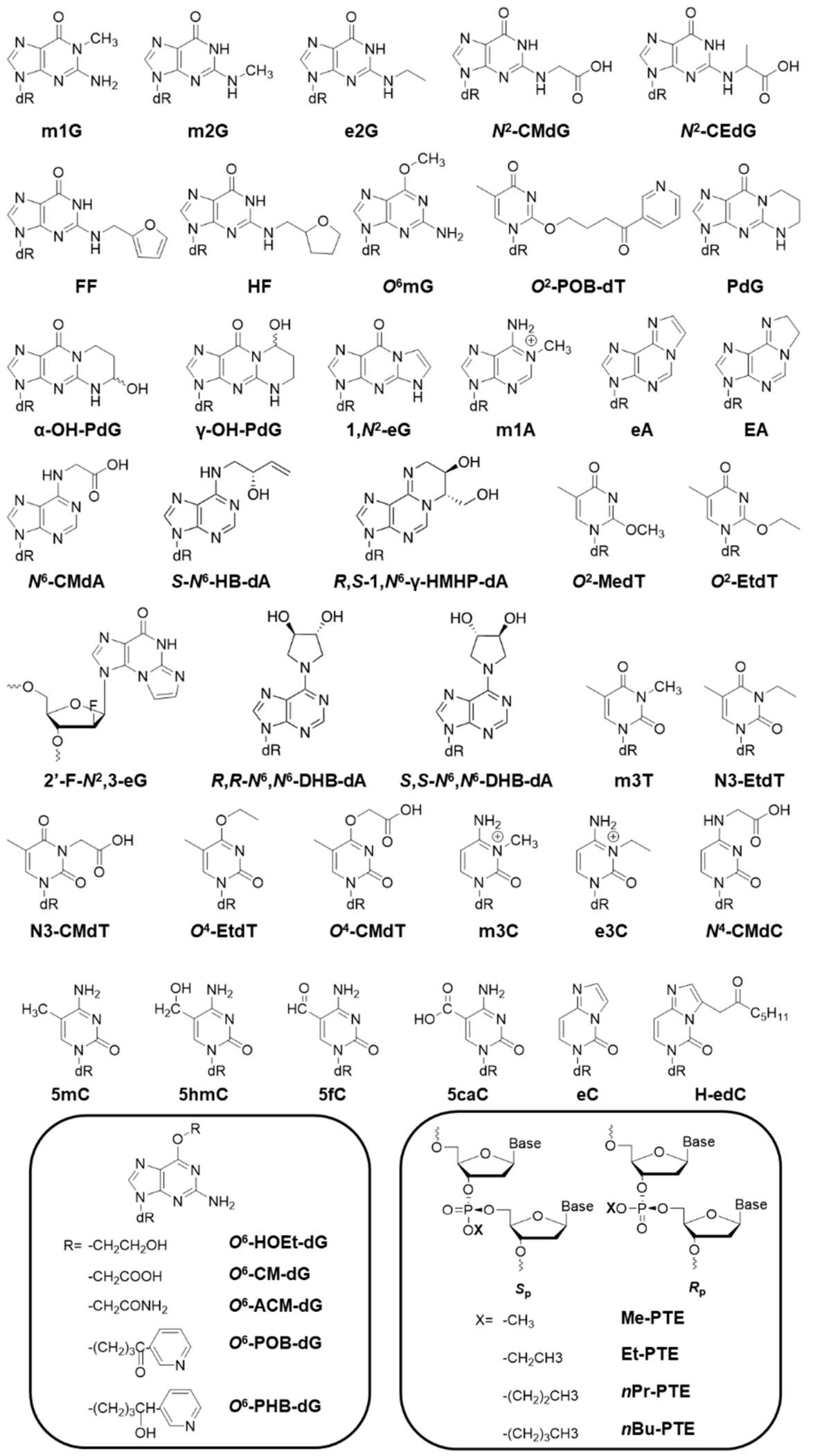

Figure 3. Structures of alkyl modifications. 

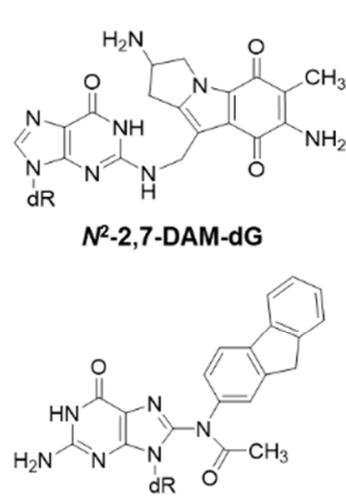

C8-AAF-dG

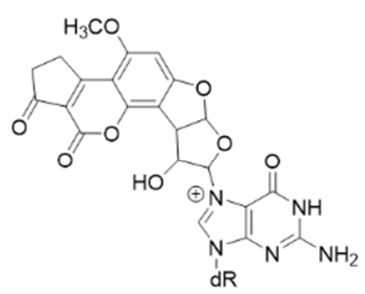

$\mathrm{AFB}_{1}$-N7-dG

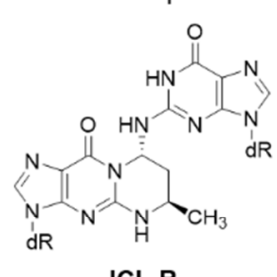

ICL-R

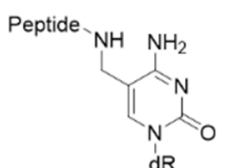

5fC mediated peptide crosslink
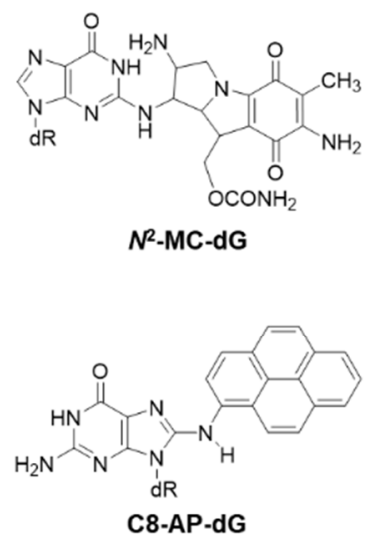

C8-AP-dG

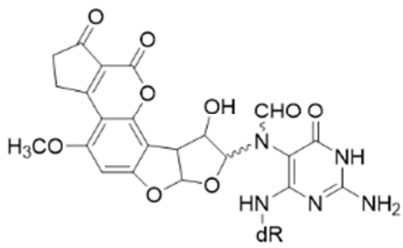

AFB $_{1}$-FAPY
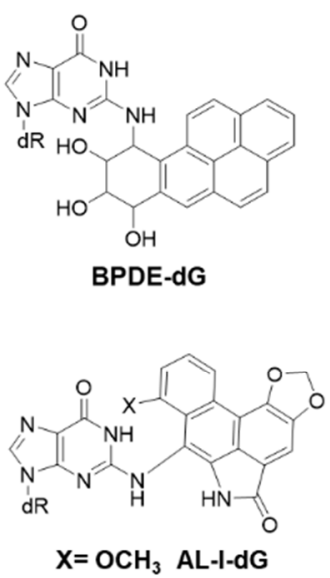

H AL-II-dG

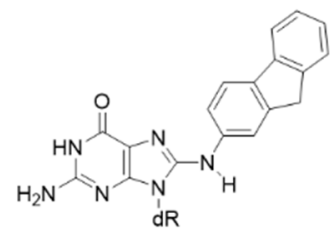

C8-AF-dG

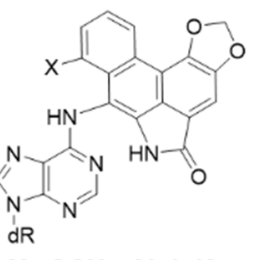

$X=\mathrm{OCH}_{3} \quad$ AL-I-dA

$H \quad A L-\| I-d A$

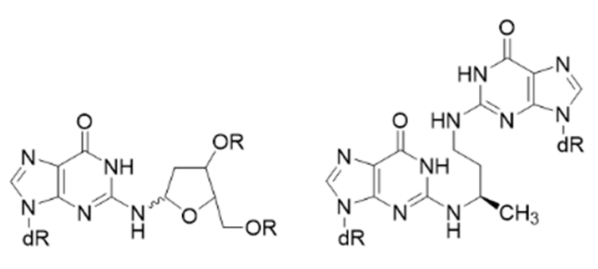

AP-dG

ICL-RD
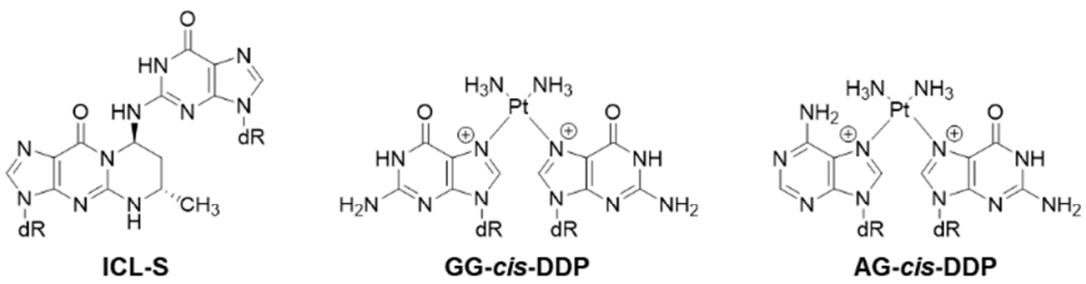

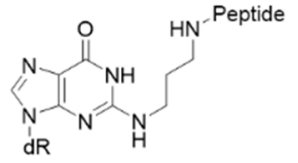

V-HOPdG mediated
peptide crosslink

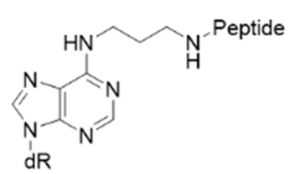

V-HOPdA mediated peptide crosslink

Figure 4. Structures of bulky and crosslinked lesions.<smiles>Cc1ccccc1</smiles>

H<smiles>Cc1cc(F)c(F)cc1F</smiles>

$F$<smiles>Cc1cc(Br)c(Cl)cc1Cl</smiles>

L<smiles>Cc1cc(Br)c(Br)cc1Br</smiles>

B

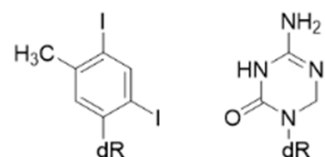

KP1212<smiles>Nc1nc2cc3c(cc2c(=O)[nH]1)ncn3[Ga]</smiles>

XG<smiles>CCn1cnc2cc3ncnc(N)c3cc21</smiles>

$x A$<smiles>O=c1[nH]c(=O)c2cccc(Br)c2[nH]1</smiles>

$\mathbf{X T}$<smiles>CCCCc1cccc2c(N)nc(=O)[nH]c12</smiles>

$\mathrm{xC}$<smiles>COCC1OC([18OH])CC1OC</smiles>

a-dN
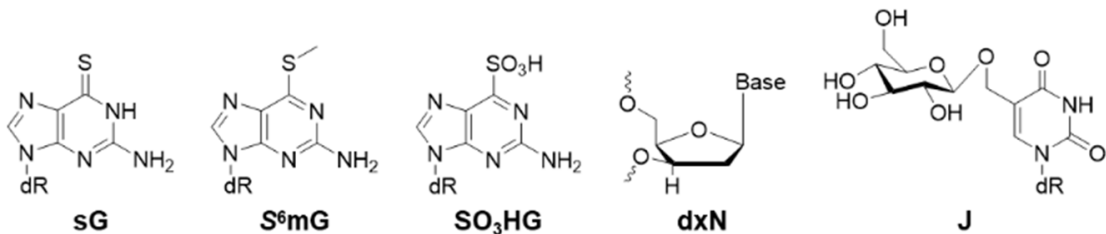

Figure 5. Structures of other nucleotide analogs. 


\subsection{Oxidative Biomarkers}

All the structures of modifications covered in this section are displayed in Figure 2. 8-Oxo-7,8dihydro-2'-deoxyguanosine (8-oxo-G) is not a strong block to replication, demonstrating greater than 80\% bypass efficiency in E. coli [28]. Its mutagenic pairing with A during replication in wild type (WT) cells leads to a low amount of G>T mutation (3\%) [28]. However, in MutY-cells (MutY: adenine glycosylase in 8-oxo-G:A base excision repair), the G>T mutation increases to $44 \%$ [29]. 8-oxo-G causes mainly G $>$ T mutation with a frequency of $8 \%$ in human cells [28,29]. Thymidine glycol $(\mathrm{Tg})$ is not a replication block, and it is not mutagenic in E. coli; however, tandem lesions of 8-oxoG and Tg are twice as effective as a single 8-oxo-G in blocking DNA replication, and the dual lesion is more mutagenic than 8-oxo-G [38]. Fapy-dG (N-(2-deoxy- $\alpha, \beta$-d-erythropentofuranosyl)-N-(2,6-diamino-4hydroxy-5-formamidopyrimidine)) strongly blocks replication by $60-70 \%$ in E. coli, but it is not very mutagenic, providing less than $2 \% \mathrm{G}>\mathrm{T}$ mutation [31]. Fapy-dG causes $10 \% \mathrm{G}>\mathrm{T}$ mutation in human cells [30]. 5-Guanidino-4-nitroimidazole (NI) strongly blocks replication (93\%) in E. coli, giving mainly $\mathrm{G}>\mathrm{T}(22 \%)$ and $\mathrm{G}>\mathrm{A}(19 \%)$ mutations, and some $\mathrm{G}>\mathrm{C}(9 \%)$ mutation as well [32]. Oxaluric acid (Oa) is toxic, blocking replication by $50 \%$, causing nearly $100 \% \mathrm{G}>\mathrm{T}$ mutation in E. coli $[28,31,34]$. Oxazalone $(\mathrm{Oz})$ strongly blocks replication and is very mutagenic, causing $86 \% \mathrm{G}>\mathrm{T}$ mutation [28]. Cyanuric acid lesion (Ca) blocks 35\% replication in E. coli, and is very mutagenic with 95\% G>T mutation [28]. Guanidinohydantoin (Gh) slightly blocks replication (25\%), and it is highly mutagenic yielding $97 \%$ $\mathrm{G}>\mathrm{C}$ and $2 \% \mathrm{G}>\mathrm{T}$ mutation [34]. Two stable stereoisomers of spiroiminodihydantoin (Sp1 and Sp2) are strong replication blocks (91\%), and are both very mutagenic, causing mainly $\mathrm{G}>\mathrm{C}$ ( $72 \%$ for Sp1 and $57 \%$ for Sp2) and G>T ( $27 \%$ for Sp1 and $41 \%$ for Sp2) mutations [34]. Urea lesion (Ur) is a strong replication block (90\%) causing 54\% G>T,35\% G>C , and 9\% G>A mutations [29,35]. Imidazolone adduct (Iz) can be bypassed in $E$. coli with a $40 \%$ blockage in replication, essentially causing G>C $(88 \%)$ mutation, with some $\mathrm{G}>\mathrm{A}(2 \%)$ and $\mathrm{G}>\mathrm{T}(1 \%)$ mutations [32]. 8,5'-Cyclo-2'-deoxyguanosine (cdG) is a strong replication block $(89 \%)$ in $E$. coli, and knocking out pol V increases its replication block; it is mutagenic and causes 20\% G>A mutation [36]. The 5' S-diastereomer of cyclo-dG (S-cdG) also strongly blocks DNA replication (96\%) in human cells, giving primarily G>T (35\%) and G>A (20\%) mutations [37]. 8,5'-Cyclo-2'-deoxyadenosine (cdA) is $31 \%$ bypassed in E. coli, but the bypass efficiency drops to $13 \%$ when pol $\mathrm{V}$ is removed from the cell [36]. It is mutagenic and causes $\mathrm{A}>\mathrm{T}$ $(11 \%)$ mutation [36]. The 5' S-diastereomer of cyclo-dA (S-cdA) strongly blocks replication in human cells by $94 \%$ [37]. Knocking down pol $\eta$ by siRNA decreases the bypass efficiency and mutagenicity of S-cdA [37]. 5-Chlorocytosine (5-Cl-dC) blocks replication (25\%), forming a low level of $\mathrm{C}>\mathrm{T}$ mutation (5\%) in E. coli [39]. 5-Hydroxycytosine (5-OH-dC) is not mutagenic in E. coli [40]. 5-Hydroxyuracil (5-OH-dU, derived from 5-OH-dC) is very mutagenic providing $83 \% \mathrm{C}>\mathrm{T}$ mutation in E. coli [40]. 5,6-Dihydroxy-5,6-dihydrouracil ( $\mathrm{Ug})$ is also very mutagenic $(80 \% \mathrm{C}>\mathrm{T})$ in E. coli [40].

Tetrahydrofuran (THF) is a stable structural analog to the abasic site (AP site), which is not stable and may lead to further damages to the DNA strand. THF strongly blocks replication $(>95 \%)$ and causes $\mathrm{G}>\mathrm{T}(50 \%), \mathrm{G}>\mathrm{C}(26 \%)$, and G>A (7\%) mutations; additionally, it causes $13 \%-1$ frame shift mutation $[28,29,32,34,80]$.

\subsection{Alkyl Biomarkers}

All the structures of modifications covered in this section are displayed in Figure 3. 1-Methyldeoxyguanosine $(\mathrm{m} 1 \mathrm{G})$ is a strong replication block either with or without the repair enzyme AlkB (85\% and 97\%); it mainly causes $\sim 3 \%$ G $>$ T mutation in WT E. coli, which increases to more than $50 \%$ in AlkB- E. coli (AlkB: alkyl DNA adduct direct reversal of damage repair protein) $[9,33] . N^{2}$-methylguanine (m2G) weakly blocks replication by $10 \%$ in $E$. coli, there is no significant change when knocking out either AlkB or DinB (DinB: DNA polymerase IV), and a small amount of G>A mutation (3\%) is seen [42]. $N^{2}$-ethylguanine (e2G) does not block replication in $E$. coli and causes a low amount of G>A mutation (2\%); eliminating AlkB and DinB does not change the replication bypass and mutagenicity significantly [42]. $N^{2}$-carboxymethyl-2'-deoxyguanosine 
$\left(N^{2}-\mathrm{CMdG}\right)$ and $N^{2}$-(1-carboxyethyl)-2'-deoxyguanosine ( $\left.N^{2}-\mathrm{CEdG}\right)$ do not block DNA replication and are not mutagenic in WT mammalian cells; however, each of them causes G>A (23\%) and G>T $(15 \%)$ mutations in mouse embryonic fibroblast (MEF) cells that are deficient in pol $\kappa$ [43]. $N^{2}$-CEdG blocks replication in E. coli [44]. The $R-N^{2}$-CEdG is a stronger replication block (61\%) than $S-N^{2}-C E d G$ (25\%); however, neither of them are mutagenic [44]. $N^{2}$-furfurylguanine ( $N^{2}$-FF-dG) does not block replication in WT E. coli; however, it blocks replication about $72 \%$ in DinB- cells [42]. It is not very mutagenic with or without DinB [42]. 2-Tetrahydrofuran-2-yl-methylguanine ( $\left.N^{2}-H F-d G\right)$ is similar in structure to $N^{2}$-FF-dG and strongly blocks replication (72\%) only when DinB is knocked out, and causes only $2 \% \mathrm{G}>\mathrm{C}$ mutation [42]. $O^{6}$-methylguanine $\left(O^{6} \mathrm{mG}\right)$ is very mutagenic and leads to almost $100 \%$ G > A mutation in Ada/Ogt/UvrB triple knockout E. coli (Ada/Ogt: alkyl DNA adduct direct reversal of damage repair protein; UvrB: nucleotide excision repair) [45,46]. $\mathrm{N}$-Nitroso compounds induce DNA lesions: $O^{6}$-pyridyloxobutyl-dG $\left(O^{6}-\mathrm{POB}-\mathrm{dG}\right), \mathrm{O}^{6}$-pyridylhydroxybutyl-dG $\left(O^{6}-\mathrm{PHB}-\mathrm{dG}\right)$, $\mathrm{O}^{6}$-carboxymethyl-dG $\left(\mathrm{O}^{6}-\mathrm{CMdG}\right)$, which have two structural analogs: $O^{6}$-aminocarbonylmethyl-dG $\left(O^{6}\right.$-ACM-dG) and $O^{6}$-hydroxyethyl-dG $\left(O^{6}\right.$-HOEt-dG) [47]. $O^{6}$-POB-dG slightly blocks DNA replication and induces $\mathrm{G}>\mathrm{A}(90 \%)$ transition and $\mathrm{G}>\mathrm{T}(2.5 \%)$ transversion in E. coli [47]. $O^{6}$-PHB-dG is a moderate impediment to DNA replication and causes G>A (95\%) mutation exclusively in $E$. coli [47]. $O^{6}-\mathrm{CMdG}$ strongly inhibits replication in E. coli, but causes moderate $\mathrm{G}>\mathrm{A}(10 \%)$ mutation [47]. $\mathrm{O}^{6}$-ACM-dG and $\mathrm{O}^{6}$-HOEt-dG are two analogs of $\mathrm{O}^{6}$-CM-dG. Both $O^{6}$-ACM-dG (2\% bypass) and $\mathrm{O}^{6}$-HOEt-dG (15\% bypass) strongly block DNA replication [47]. They also induce G>A mutation with $30 \%$ and $40 \%$ frequencies, respectively [47]. Major acrolein-dG adducts include $8 \alpha$ and $8 \beta$ isomers of 3H-8-hydroxy-3-( $\beta$-D-2'-deoxyribofuranosyl)-5,6,7,8-tetrahydropyrido[3,2-a]purine-9-one ( $\gamma$-OH-PdG), $6 \alpha$ and $6 \beta$ isomers ( $\alpha$-OH-PdG), and 1, $N^{2}-\left(1,3\right.$-propano)- $2^{\prime}$-deoxyguanosine (PdG) [12]. The bypass efficiency for $\gamma$-OH-PdG is $73 \%$ compared to dG control in human cells, and $\gamma$-OH-PdG is not very mutagenic $(<1 \%)$ [12]. $\alpha-\mathrm{OH}-\mathrm{PdG}$ strongly blocks DNA replication with a bypass efficiency of $17 \%$ in human cells and it causes G $>$ T (11\%) mutation [13]. PdG strongly blocks replication in human cells and mainly causes 6\% G>T mutation [12]. Most of the derivatives of PdG moderately block DNA replication in human cells and cause mainly G>T mutation (2-8\%) [81]. 1, $N^{2}$-ethenoguanine $\left(1, N^{2}-\mathrm{eG}\right)$ is a strong replication blocker $(96 \%)$ in E. coli and causes $\mathrm{G}>\mathrm{A}$ and $\mathrm{G}>\mathrm{T}$ mutation by $6 \%$ for both, plus a small amount of $\mathrm{G}>\mathrm{C}(2 \%)$ mutation; it also causes -1 and -2 frame shift mutations $(5 \%)$, and knocking out AlkB leads to higher replication block and almost doubles the mutagenicity [8]. $2^{\prime}$-Fluoro- $N^{2}, 3-\varepsilon-2^{\prime}$-deoxyarabinoguanosine $\left(2^{\prime}-\mathrm{F}-N^{2}, 3-\mathrm{eG}\right)$, a stable analog of $N^{2}, 3$-ethenoguanine $\left(N^{2}, 3-\mathrm{eG}\right)$, blocks replication by $79 \%$, and causes $30 \% \mathrm{G}>\mathrm{A}$ mutation in $E$. coli, with AlkB having no significant influence in its replication bypass and mutagenicity [8].

1-Methyldeoxyadenosine (m1A) strongly blocks replication in AlkB- E. coli $(88 \%)$, but it is not very mutagenic, causing $<1 \% \mathrm{~A}>\mathrm{T}$ mutation; m1A does not block replication in AlkB+ E. coli cells [9]. $1, N^{6}$-ethenoadenine (eA) weakly blocks replication by $4 \%$ in WT E. coli, but significantly blocks replication (95\%) when AlkB is knocked out; likewise, eA is not mutagenic in WT E. coli, but shows strong mutagenicity in AlkB- cells (25\% A $>$ T mutation) [33,49]. Bypass efficiency of eA in human cells is $17 \%$ [50]. 1, $N^{6}$-ethanoadenine (EA) does not block replication in WT E. coli, but strongly blocks replication by $86 \%$ when AlkB is removed; it is not very mutagenic in either WT or AlkB- cells, causing only $2 \%$ A $>C$ mutations [49]. $N^{6}$-carboxymethyl-2'-deoxyadenosine ( $N^{6}$-CMdA) minimally blocks replication in E. coli and is not mutagenic [36]. S- $N^{6}-\mathrm{HB}-\mathrm{dA}$ (HB = 2-hydroxy-3-buten-1-yl) and $R, R-N^{6}{ }^{6} N^{6}$-DHB-dA (DHB = 2,3-dihydroxybutan-1,4-diyl) do not block DNA replication and are not mutagenic in E. coli [51]. $S, S-N^{6}, N^{6}$-DHB-dA moderately inhibits replication with a $60 \%$ bypass efficiency, and causes minimal $1 \% \mathrm{~A}>\mathrm{G}$ mutation [51]. R,S-1, $N^{6}-\gamma$-HMHP-dA (HMHP $=$ 2-hydroxy-3-hydroxymethylpropan-1,3-diyl) strongly inhibits DNA replication but causes only 2\% A $>$ T mutation [51].

$\mathrm{O}^{2}$-Methylthymidine $\left(\mathrm{O}^{2}\right.$-Me-dT) can be bypassed by $55 \%$ in human cells and mainly causes $\mathrm{T}>\mathrm{A}$ mutation (56\%) [53]. $\mathrm{O}^{2}$-[4-(3-pyridyl-4-oxobut-1-yl]thymidine $\left(\mathrm{O}^{2}\right.$-POB-dT) exhibits genotoxicity showing $26 \%$ bypass efficiency and is mutagenic with $47 \% \mathrm{~T}>\mathrm{A}$ transversion [53]. Both $\mathrm{O}^{2}$-Me-dT 
and $O^{2}$-POB-dT strongly block DNA replication in E. coli (95\% and 97\%) [54]. $O^{2}$-Me-dT induces $10 \% \mathrm{~T}>\mathrm{A}$ and $10 \% \mathrm{~T}>\mathrm{G}$ mutations [54]. $\mathrm{O}^{2}$-POB-dT induces $38 \% \mathrm{~T}>\mathrm{G}$ and $12 \% \mathrm{~T}>\mathrm{A}$ mutations [54]. $\mathrm{O}^{2}$-Ethylthymidine $\left(\mathrm{O}^{2}\right.$-EtdT) is a strong replication block (79\%) in E. coli, and knocking out pol IV increases the blocking activity, while knocking out pol $\mathrm{V}$ increases the replication block even more [55]. It is very mutagenic and forms $\mathrm{T}>\mathrm{C}(35 \%), \mathrm{T}>\mathrm{A}(15 \%)$, and $\mathrm{T}>\mathrm{G}(5 \%)$ mutations, and mutation frequency drops when pol $\mathrm{V}$ is knocked out [55]. The bypass efficiency of $O^{2}$-dT alkyl adducts in E. coli depends on the size of the alkyl lesion [82]. More than $20 \%$ of adducts can be bypassed during replication for ethyl and methyl substitutions, but less than $10 \%$ can be bypassed for propyl, and less than $5 \%$ for butyl adducts, with the major mutation type being $\mathrm{T}>\mathrm{C}$ point mutation [82]. $\mathrm{O}^{2}$-alkyldT lesions strongly inhibit DNA replication (40-85\%) in mammalian cells [52]. The blockage effect increases with the size and branching of the alkyl groups [52]. These lesions cause $\mathrm{T}>\mathrm{A}$ and $\mathrm{T}>\mathrm{G}$ mutations [52]. 3-Methyldeoxythymidine (m3T) strongly blocks replication in E. coli by $94 \%$ and is very mutagenic, generating mainly $\mathrm{T}>\mathrm{A}(32 \%)$ transversion mutation; eliminating AlkB slightly increases its replication blocking power and mutagenicity [9]. N3-Ethylthymidine (N3-EtdT) strongly blocks replication by 83\% in E. coli, and knocking out pol V or pol IV increases its blocking activity; it is very mutagenic causing $\mathrm{T}>\mathrm{A}(21 \%), \mathrm{T}>\mathrm{C}(15 \%)$ and $\mathrm{T}>\mathrm{G}(3 \%)$ mutations, and removing pol $\mathrm{V}$ eliminates the mutagenicity of this adduct [55]. N3-carboxymethylthymidine (N3-CMdT) strongly blocks replication by $45 \%$ in E. coli, with the major mutation being $\mathrm{T}>\mathrm{A}(66 \%)$; and knocking out pol V slightly increases the mutation rate; however, knocking out pol IV decreases the mutation rate [36]. $\mathrm{O}^{4}$-carboxymethylthymidine $\left(\mathrm{O}^{4}-\mathrm{CMdT}\right)$ is a strong replication block $(51 \%)$ and very mutagenic, causing $86 \% \mathrm{~T}>\mathrm{C}$ mutation [36]. $\mathrm{N}^{3}$-CMdT, $\mathrm{O}^{4}-\mathrm{CMdT}$ and $\mathrm{O}^{6}$-carboxymethyl-dG $\left(\mathrm{O}^{6}-\mathrm{CMdG}\right)$ moderately block DNA replication in human cells [48]. $\mathrm{N}^{3}$-CMdT causes $\mathrm{T}>\mathrm{A}(81 \%)$ mutation; $\mathrm{O}^{4}$-CMdT causes $\mathrm{T}>\mathrm{C}(68 \%)$ mutation; $\mathrm{O}^{6}$-CMdG causes $\mathrm{G}>\mathrm{A}(6.4 \%)$ mutation; neither $\mathrm{N}^{6}$-CMdA nor $\mathrm{N}^{4}$-CMdC block replication or induce mutation [48]. $\mathrm{O}^{4}$-Ethylthymidine $\left(\mathrm{O}^{4}\right.$-EtdT) does not strongly block replication (24\%) in WT E. coli, but it cannot be efficiently bypassed in pol II/IV/V triple knock out cells [55]. The major mutation of $\mathrm{O}^{4}$-EtdT is T>C (84\%) transition; however, it does not cause mutations in E. coli lacking pol V [55]. $\mathrm{O}^{4}$-Alkylthymidine $\left(\mathrm{O}^{4}\right.$-alkyldT) lesions moderately block DNA replication in human cells; pol $\iota$ and pol $\zeta$ promote the bypass of all $O^{4}$-alkyldT lesions except $O^{4}$-MedT [56]. The $O^{4}$-alkyldT lesions induce only $\mathrm{T}>\mathrm{C}$ transition mutations in cells [56].

3-Methyldeoxycytidine (m3C) has been demonstrated to strongly block replication ( $>90 \%)$ and generate mainly $\mathrm{C}$ to $\mathrm{T}(50 \%)$ and $\mathrm{C}$ to A mutations (30\%) in the AlkB- E. coli cell [9]. However, the lesion is not mutagenic and not blocked by the replicative polymerases in the WT (AlkB+) cell [9]. 3-Ethyldeoxycytidine (e3C) does not block replication in E. coli; however, it dramatically blocks replication when knocking out $\mathrm{AlkB}(91 \%)$ [9]. e3C causes $17 \% \mathrm{C}>\mathrm{T}, 11 \% \mathrm{C}>\mathrm{A}$, and $2 \% \mathrm{C}>\mathrm{G}$ mutations in AlkB- E. coli, but is not mutagenic in WT cells [9]. The m3C, e3C, and m1A lesions presumably have their methyl or ethyl groups removed by AlkB's direct reversal of DNA alkyl damage mechanism prior to encountering the DNA polymerase [9]. $N^{4}$-carboxymethyl-2'-deoxycytidine ( $\left.N^{4}-\mathrm{CMdC}\right)$ weakly blocks replication (17\%) and is not mutagenic in E. coli [36]. 5-Methylcytosine (5mC) and its derivatives 5-hydroxymethylcytosine ( $5 \mathrm{hmC}$ ), 5-formylcytosine (5fC) and 5-carboxylcytosine (5caC) neither block replication nor cause mutation in E. coli $[39,59] .5 \mathrm{mC}$ also does not block replication in human cells, but there are some blockades of $5 \mathrm{hmC}(5 \%), 5 \mathrm{fC}(25 \%)$, and $5 \mathrm{caC}(28 \%)$ towards DNA replication in human cells [58]. 3, $\mathrm{N}^{4}$-ethenocytosine $(\mathrm{eC})$ is a toxic adduct, which strongly blocks replication $(76 \%)$ and leads to mutation with a pattern of dominant $\mathrm{C}>\mathrm{A}(24 \%)$ and less $\mathrm{C}>\mathrm{T}(11 \%)$ mutations in WT E. coli; in AlkB- cells, the blockage of replication increases to $87 \%$ and mutagenicity rises up to $49 \%$ $\mathrm{C}>\mathrm{A}$ and $31 \% \mathrm{C}>\mathrm{T}$ mutations [33]. Lipid peroxidation-derived product 4-oxo-2(E)-nonenal reacts with $\mathrm{dG}, \mathrm{dA}$, and $\mathrm{dC}$ in DNA to form heptanone (H)-etheno (e) adducts [50]. H-edC shows strong DNA replication blocking in both E. coli (99\%) and human cells (90\%) [50]. It causes mainly C>G (40\%) mutation in E. coli; however, mostly $\mathrm{C}>\mathrm{A}(60 \%)$ and $\mathrm{C}>\mathrm{T}(32 \%)$ mutations are seen in human cells [50].

5 -Hydroxymethyluracil (5hmU) blocks replication by $20 \%$, but it is not mutagenic in human cells [60]. The $S_{\mathrm{p}}$ alkyl phosphotriester ( $S_{\mathrm{p}}$-alkyl-PTE) lesions display comparable replication 
bypass efficiency to unmodified DNA in E. coli; $S_{\mathrm{p}}$-Me-PTE is mutagenic causing TT>GT $(50 \%)$ and TT>GC (15\%) mutations [61]. In contrast, $R_{\mathrm{p}}$-alkyl-PTEs block DNA replication (30-70\%) but are not mutagenic [61]. Interestingly, $n \mathrm{Pr}-$ and $n \mathrm{Bu}-\mathrm{PTEs}$ exhibit higher bypass efficiencies than Me- and Et-PTEs [61].

\subsection{Bulky Lesions}

All the structures of modifications covered in this section are displayed in Figure 4. $N$-(deoxyguanosin-8-yl)-1-aminopyrene (C8-AP-dG) moderately blocks DNA replication in human cells [66]. $\mathrm{N}$-acetyl-2-aminofluorene (C8-AAF-dG) strongly blocks replication [66]. 2-Aminofluorene (C8-AF-dG) slightly blocks replication [66]. All three adducts can be nearly bypassed in error free manner [66]. Aristolochic acids I and II (AA-I, AA-II) are found in all Aristolochia species and generate the aristolactam (AL) metabolite for forming DNA adducts with dA and dG. Both AL-II-dA and AL-II-dG strongly block DNA replication in MEF cells [63]. AL-II-dA causes 22\% A>T mutation and AL-II-dG causes 9\% G $>$ T transversion [63]. Knocking out the rev3L gene dramatically suppresses bypass of AL-I-dA in MEF cells and abolishes $\mathrm{A}>\mathrm{T}$ transversion [67]. Benzo[a]pyrene (BP)-7,8-diol-9,10-epoxide- $N^{2}$-deoxyguanosine (BPDE-dG) is an adduct formed by benzo[ $\left.a\right]$ pyrene; it predominantly miscodes with G>T (73\%) and G>A (12\%) mutations in WT MEF cells [68]. Knocking out rev1 gene decreases the bypass efficiency of BPDE-dG to $40 \%$ and changes the mutation frequency to $32 \% \mathrm{G}>\mathrm{T}$ and $18 \% \mathrm{G}>\mathrm{A}$ [68]. Knocking out the rev3L gene significantly decreases the bypass efficiency to $13 \%$ and decreases the mutation to $6 \% \mathrm{G}>\mathrm{T}$ [68]. Mitomycin C (MC) generates dG-N2-MC and dG-N2-2,7-Diaminomitosene (DAM) adducts, which can be bypassed $38 \%$ and $27 \%$ in human cells, respectively [62]. The major type of mutation is G>T mutation (18\% for dG-N2-MC and $10 \%$ for dG-N2-2,7-DAM) [62]. Aflatoxin $\mathrm{B}_{1}-\mathrm{N} 7-\mathrm{dG}$ adduct ( $\left.\mathrm{AFB}_{1}-\mathrm{N} 7-\mathrm{dG}\right)$ is weakly mutagenic in E. coli, causing 1.5\% G>T mutation [64]; and its FAPY adduct causes 14\% G>T mutation [65].

\subsection{Crosslinked Lesions}

All the structures of modifications covered in this section are displayed in Figure $4 . N^{2}$-guanine - $N^{2}$-guanine interstrand crosslinks (ICLs), 3-(2-deoxyribos-1-yl)-5,6,7,8-( $N^{2}$-deoxyguanosyl)-6(either R or S)-methylpyrimido[1,2-R]purine-10(3H)-one is a product induced by acetaldehyde/crotonaldehyde [69]. ICL-S and ICL-R moderately inhibit DNA replication in WT E. coli; however, their replication blocking effects increase in uvr- E. coli cells [69]. ICL-Rd is a moderate block in WT E. coli, but it almost completely blocks replication in uvr- cells [69]. All three lesions are weakly mutagenic in E. coli causing exclusively $5^{\prime}-\mathrm{G}>\mathrm{T}(3 \%)$ transversions; no mutation is observed at the $3^{\prime}-\mathrm{G}$ site [69]. Similar mutations generated by these lesions are seen in human cells, except ICL-S has a slightly higher mutation frequency (6\%) [69]. The crosslinks formed by cis-diaminedichloroplatinum (II) (cis-DDP, cisplatin) between two guanines or adenine-guanine strongly block DNA replication in E. coli, but they are not very mutagenic [72]. 5-Formylcytosine mediated peptide crosslink causes $7 \% \mathrm{C}>\mathrm{T}$ and $1 \% \mathrm{C}>\mathrm{G}$ mutation and $2 \% \mathrm{C}$ deletion [73]. $\gamma$-Hydroxypropanodeoxyguanosine ( $\gamma$-HOPdG) mediated crosslink between peptide and guanine is mutagenic, causing $5 \% \mathrm{G}>\mathrm{T}$ and $3 \% \mathrm{G}>\mathrm{C}$ mutations; however, the crosslink between peptide and $\gamma$-hydroxypropanodeoxyadenine ( $\gamma$-HOPdA) is not mutagenic [20].

\subsection{Other Nucleotide Analogs}

All the structures of modifications covered in this section are displayed in Figure 5. A series of unnatural analogs of thymine (T) was developed by the Kool group to probe the biological requirements for DNA polymerases [74]. 3-Toluene-1- $\beta$-D-deoxyriboside $(\mathrm{H})$ strongly blocks replication (95\%) and is very mutagenic causing $\mathrm{T}>\mathrm{A}(41 \%), \mathrm{T}>\mathrm{C}(5 \%)$, and $\mathrm{T}>\mathrm{G}(4 \%)$ point mutations and -1 frame shift mutation (13\%). 2,4-Difluoro-5-toluene-1- $\beta$-D-deoxyriboside (F) strongly blocks replication $(87 \%)$ and is mutagenic causing $\mathrm{T}>\mathrm{A}(9 \%), \mathrm{T}>\mathrm{C}(1 \%)$, and $\mathrm{T}>\mathrm{G}(1 \%)$ mutations. 2,4-Dichloro-5-toluene-1- $\beta$-D-deoxyriboside (L) strongly blocks replication (80\%) and is slightly mutagenic causing $\mathrm{T}>\mathrm{A}(5 \%)$ mutation. 2,4-Dibromo-5-toluene-1- $\beta$-D-deoxyriboside 
(B) strongly blocks replication (88\%) and is mutagenic, causing $\mathrm{T}>\mathrm{A}(24 \%)$ mutation. 2,4-Diiodo-5-toluene-1- $\beta$-D-deoxyriboside (I) strongly blocks replication $(90 \%)$ and is very mutagenic causing $\mathrm{T}>\mathrm{A}(46 \%), \mathrm{T}>\mathrm{C}(1 \%)$, and $\mathrm{T}>\mathrm{G}(1 \%)$ point mutations and -1 frame shift mutation (6\%) [74]. $x \mathrm{G}$ is an 'expanded base' of $\mathrm{dG}$ (retaining the hydrogen-bonding face), which strongly blocks replication $(89 \%)$ and is very mutagenic, causing G>A (95\%) mutation [75]. xA (expanded A) weakly blocks replication (20\%) and is not mutagenic; xT (expanded T) weakly blocks replication (27\%), but is very mutagenic, causing $\mathrm{T}>\mathrm{A}(73 \%)$ mutation; $\mathrm{xC}$ (expanded $\mathrm{dC}$ ) strongly blocks replication $(71 \%)$ and is mutagenic, causing $\mathrm{C}>\mathrm{A}(10 \%)$ mutation [75].

The $\alpha$-anomer of deoxynucleosides $(\alpha-\mathrm{dN})$ can be generated as a result of hydroxyl radical attack on deoxyribose [76]. All $\alpha$-dNs except $\alpha$-dA strongly block replication in E. coli [76]. $\alpha$-dC blocks almost $99 \%$ replication and causes $72 \% \mathrm{C}>\mathrm{A}$ mutation [76]. $\alpha$-dG also strongly blocks replication and causes $60 \% \mathrm{G}>\mathrm{A}$ mutation [76]. $\alpha$-dT blocks almost $99 \%$ replication but it is not mutagenic in WT E. coli [76]. $\alpha$-dA is not mutagenic [76]. The anticancer agent 6-thioguanine (sG) and its derivative $S^{6}$-methylthioguanine $\left(S^{6} \mathrm{mG}\right)$ do not block replication strongly in both E. coli and human cells [78]. sG causes $11 \% \mathrm{G}>\mathrm{A}$ mutation and $S^{6} \mathrm{mG}$ causes $94 \% \mathrm{G}>\mathrm{A}$ mutation in $E$. coli [78]. $\mathrm{sG}$ is less mutagenic $(8 \%)$ than $S^{6} \mathrm{mG}(40 \%)$ in human cells as well [78]. Guanine- $S^{6}$-sulfonic acid $\left(\mathrm{SO}_{3} \mathrm{HG}\right)$ is another derivative of $\mathrm{sG}$ [78]. It is not a strong replication block in $E$. coli, but it is very mutagenic, causing $77 \%$ G $>$ A mutation [78]. The anti-HIV drug KP1212 is an analog of deoxycytidine [57]. It does not block replication in E. coli, but is mutagenic causing $10 \% \mathrm{C}>\mathrm{T}$ mutation [57]. Among the four 2'-deoxyxylonucleosides $(\mathrm{xN})$, only $\mathrm{xA}$ and $\mathrm{xG}$ exhibit a replication block in E. coli [77]. $\mathrm{xA}$ is the only mutagenic lesion among the four and causes $10 \% \mathrm{~A}>\mathrm{G}$ mutation [77]. Base J strongly blocks replication by $48 \%$, but is not mutagenic in human cells [60].

\section{Perspectives}

In this review, we survey the biological effects of various DNA lesions or biomarkers studied by the shuttle vector techniques, allowing one to gain insight into how DNA damage or other chemically defined nucleobases are processed by polymerases and repair machinery in a natural cellular environment under physiological conditions. Among the new methods that have been developed or applied in the last decade, MS-based strategies and NGS methods have been demonstrated to be efficient for analyzing the lesion's biological outcomes. LC-MS-based methods are sensitive and accurate for quantifying the degree of lesion bypass and point mutations [4,5]. NGS techniques allow for a large-scale population analysis on many samples at the same time and provide information on a genomic perspective $[4,8]$. Another possible direction for using vectors as probes to analyze biomarkers is to study the mutational spectrum or mutational signature of a certain chemical or damaging agent [83-86]. LC-MS- and NGS-based analyses not only consider the biological consequences at the lesion site, but also incorporate information from the neighboring bases, such as one or two nucleotides next to the lesion site from both the $5^{\prime}$ and $3^{\prime}$ direction. An oligonucleotide containing the modified base can be made surrounded by nearest (and next-to nearest) randomized bases and ligated into a shuttle vector. While cellular analysis may pull out a hotspot consensus sequence for poor repair and/or mutagenic replication, this will not answer the primary question of contextual bias in adduct formation. Shuttle vector systems whereby the vector is treated with the chemical to be assessed, followed by quantification of adduct type and amount, and transfection into isogenic cells of varying repair and/or replication backgrounds may tease apart the contribution of local sequence environment to adduct formation, repair, and replication. Such vectors were used over a decade ago [87], and coupled with NGS throughput and bioinformatics, may provide enough reads to make statistically significant claims. Shuttle vectors are currently, to our knowledge, mainly DNA-based; however, one can envision use of RNA-based vectors to study the effect of modified RNA bases on cellular processes such as viral replication, translation, reverse transcription, and possibly even repair. While the role of DNA damage in toxicology focuses mainly on the direct adduction of chemical damage to DNA, pool mutagenesis has often been overlooked, and it would be interesting to leverage shuttle vector techniques to study 
the incorporation of modified bases from the nucleotide pool in the form of damaged DNA or from DNA-based therapeutics.

Author Contributions: Conceptualization, K.B. and D.L.; writing—original draft preparation, K.B., J.C.D., X.Z. and D.L.; writing - review and editing, K.B., J.C.D., X.Z. and D.L.; supervision, D.L.; funding acquisition, D.L.

Funding: This work was supported by National Institutes of Health under grant numbers R15 CA213042 and R01 ES028865 (to D.L.).

Acknowledgments: The authors want to thank the RI-INBRE program and its director Bongsup Cho for their kind support.

Conflicts of Interest: The authors declare no conflict of interest.

\section{References}

1. Hwa Yun, B.; Guo, J.; Bellamri, M.; Turesky, R.J. DNA adducts: Formation, biological effects, and new biospecimens for mass spectrometric measurements in humans. Mass Spectrom. Rev. 2018, 1-28. [CrossRef] [PubMed]

2. Delaney, J.C.; Essigmann, J.M. Biological properties of single chemical-DNA adducts: A twenty year perspective. Chem. Res. Toxicol. 2008, 21, 232-252. [CrossRef] [PubMed]

3. Miller, E.C. Some current perspectives on chemical carcinogenesis in humans and experimental animals: Presidential Address. Cancer Res. 1978, 38, 1479-1496.

4. Yu, Y.; Wang, P.; Cui, Y.; Wang, Y. Chemical Analysis of DNA Damage. Anal. Chem. 2018, 90, 556-576. [CrossRef] [PubMed]

5. You, C.; Wang, Y. Mass Spectrometry-Based Quantitative Strategies for Assessing the Biological Consequences and Repair of DNA Adducts. Acc. Chem. Res. 2016, 49, 205-213. [CrossRef]

6. Shrivastav, N.; Li, D.; Essigmann, J.M. Chemical biology of mutagenesis and DNA repair: Cellular responses to DNA alkylation. Carcinogenesis 2010, 31, 59-70. [CrossRef] [PubMed]

7. Delaney, J.C.; Essigmann, J.M. Assays for determining lesion bypass efficiency and mutagenicity of site-specific DNA lesions in vivo. Meth. Enzymol. 2006, 408, 1-15. [PubMed]

8. Chang, S.; Fedeles, B.I.; Wu, J.; Delaney, J.C.; Li, D.; Zhao, L.; Christov, P.P.; Yau, E.; Singh, V.; Jost, M.; et al. Next-generation sequencing reveals the biological significance of the $\mathrm{N}^{2}, 3$-ethenoguanine lesion in vivo. Nucleic Acids Res. 2015, 43, 5489-5500. [CrossRef]

9. Delaney, J.C.; Essigmann, J.M. Mutagenesis, genotoxicity, and repair of 1-methyladenine, 3-alkylcytosines, 1-methylguanine, and 3-methylthymine in alkB Escherichia coli. Proc. Natl. Acad. Sci. USA 2004, 101, 14051-14056. [CrossRef]

10. Loechler, E.L.; Green, C.L.; Essigmann, J.M. In vivo mutagenesis by $\mathrm{O}^{6}$-methylguanine built into a unique site in a viral genome. Proc. Natl. Acad. Sci. USA 1984, 81, 6271-6275. [CrossRef]

11. Green, C.L.; Loechler, E.L.; Fowler, K.W.; Essigmann, J.M. Construction and characterization of extrachromosomal probes for mutagenesis by carcinogens: Site-specific incorporation of $\mathrm{O}^{6}$-methylguanine into viral and plasmid genomes. Proc. Natl. Acad. Sci. USA 1984, 81, 13-17. [CrossRef] [PubMed]

12. Yang, I.-Y.; Johnson, F.; Grollman, A.P.; Moriya, M. Genotoxic mechanism for the major acrolein-derived deoxyguanosine adduct in human cells. Chem. Res. Toxicol. 2002, 15, 160-164. [CrossRef] [PubMed]

13. Yang, I.-Y.; Chan, G.; Miller, H.; Huang, Y.; Torres, M.C.; Johnson, F.; Moriya, M. Mutagenesis by acrolein-derived propanodeoxyguanosine adducts in human cells. Biochemistry 2002, 41, 13826-13832. [CrossRef] [PubMed]

14. Livneh, Z.; Cohen, I.S.; Paz-Elizur, T.; Davidovsky, D.; Carmi, D.; Swain, U.; Mirlas-Neisberg, N. High-resolution genomic assays provide insight into the division of labor between TLS and HDR in mammalian replication of damaged DNA. DNA Repair (Amst.) 2016, 44, 59-67. [CrossRef] [PubMed]

15. Ziv, O.; Diamant, N.; Shachar, S.; Hendel, A.; Livneh, Z. Quantitative measurement of translesion DNA synthesis in mammalian cells. Methods Mol. Biol. 2012, 920, 529-542. [PubMed]

16. Huang, H.; Greenberg, M.M. Hydrogen bonding contributes to the selectivity of nucleotide incorporation opposite an oxidized abasic lesion. J. Am. Chem. Soc. 2008, 130, 6080-6081. [CrossRef] [PubMed]

17. Greenberg, M.M. The formamidopyrimidines: Purine lesions formed in competition with 8-oxopurines from oxidative stress. Acc. Chem. Res. 2012, 45, 588-597. [CrossRef] [PubMed] 
18. Bose, A.; Millsap, A.D.; DeLeon, A.; Rizzo, C.J.; Basu, A.K. Translesion Synthesis of the $N^{2}{ }^{2}{ }^{\prime}$-Deoxyguanosine Adduct of the Dietary Mutagen IQ in Human Cells: Error-Free Replication by DNA Polymerase $k$ and Mutagenic Bypass by DNA Polymerases $\eta, \zeta$, and Rev1. Chem. Res. Toxicol. 2016, 29, 1549-1559. [CrossRef] [PubMed]

19. Basu, A.K. DNA Damage, Mutagenesis and Cancer. Int. J. Mol. Sci. 2018, 19, 970. [CrossRef]

20. Minko, I.G.; Kozekov, I.D.; Kozekova, A.; Harris, T.M.; Rizzo, C.J.; Lloyd, R.S. Mutagenic potential of DNA-peptide crosslinks mediated by acrolein-derived DNA adducts. Mutat. Res. 2008, 637, 161-172. [CrossRef]

21. Fernandes, P.H.; Wang, H.; Rizzo, C.J.; Lloyd, R.S. Site-specific mutagenicity of stereochemically defined $1, N^{2}$-deoxyguanosine adducts of trans-4-hydroxynonenal in mammalian cells. Environ. Mol. Mutagen. 2003, 42, 68-74. [CrossRef] [PubMed]

22. Benasutti, M.; Ezzedine, Z.D.; Loechler, E.L. Construction of an Escherichia coli vector containing the major DNA adduct of activated benzo[ $a$ ]pyrene at a defined site. Chem. Res. Toxicol. 1988, 1, 160-168. [CrossRef] [PubMed]

23. Grueneberg, D.A.; Ojwang, J.O.; Benasutti, M.; Hartman, S.; Loechler, E.L. Construction of a human shuttle vector containing a single nitrogen mustard interstrand, DNA-DNA cross-link at a unique plasmid location. Cancer Res. 1991, 51, 2268-2272. [PubMed]

24. Fuchs, R.P.; Fujii, S. Translesion DNA synthesis and mutagenesis in prokaryotes. Cold Spring Harb. Perspect. Biol. 2013, 5, a012682. [CrossRef] [PubMed]

25. Fuchs, R.P.; Fujii, S. Translesion synthesis in Escherichia coli: Lessons from the NarI mutation hot spot. DNA Repair (Amst.) 2007, 6, 1032-1041. [CrossRef] [PubMed]

26. Pagès, V. Single-strand gap repair involves both RecF and RecBCD pathways. Curr. Genet. 2016, 62, 519-521. [CrossRef] [PubMed]

27. Pagès, V.; Fuchs, R.P. Inserting Site-Specific DNA Lesions into Whole Genomes. Methods Mol. Biol. 2018, 1672, 107-118. [PubMed]

28. Henderson, P.T.; Delaney, J.C.; Gu, F.; Tannenbaum, S.R.; Essigmann, J.M. Oxidation of 7,8-dihydro-8-oxoguanine affords lesions that are potent sources of replication errors in vivo. Biochemistry 2002, 41, 914-921. [CrossRef] [PubMed]

29. Delaney, S.; Neeley, W.L.; Delaney, J.C.; Essigmann, J.M. The substrate specificity of MutY for hyperoxidized guanine lesions in vivo. Biochemistry 2007, 46, 1448-1455. [CrossRef] [PubMed]

30. Pande, P.; Haraguchi, K.; Jiang, Y.-L.; Greenberg, M.M.; Basu, A.K. Unlike catalyzing error-free bypass of 8-oxodGuo, DNA polymerase $\lambda$ is responsible for a significant part of Fapy·dG-induced $G \rightarrow$ T mutations in human cells. Biochemistry 2015, 54, 1859-1862. [CrossRef]

31. Patro, J.N.; Wiederholt, C.J.; Jiang, Y.L.; Delaney, J.C.; Essigmann, J.M.; Greenberg, M.M. Studies on the replication of the ring opened formamidopyrimidine, Fapy·dG in Escherichia coli. Biochemistry 2007, 46, 10202-10212. [CrossRef] [PubMed]

32. Neeley, W.L.; Delaney, J.C.; Henderson, P.T.; Essigmann, J.M. In vivo bypass efficiencies and mutational signatures of the guanine oxidation products 2-aminoimidazolone and 5-guanidino-4-nitroimidazole. J. Biol. Chem. 2004, 279, 43568-43573. [CrossRef] [PubMed]

33. Delaney, J.C.; Smeester, L.; Wong, C.; Frick, L.E.; Taghizadeh, K.; Wishnok, J.S.; Drennan, C.L.; Samson, L.D.; Essigmann, J.M. AlkB reverses etheno DNA lesions caused by lipid oxidation in vitro and in vivo. Nat. Struct. Mol. Biol. 2005, 12, 855-860. [CrossRef] [PubMed]

34. Henderson, P.T.; Delaney, J.C.; Muller, J.G.; Neeley, W.L.; Tannenbaum, S.R.; Burrows, C.J.; Essigmann, J.M. The hydantoin lesions formed from oxidation of 7,8-dihydro-8-oxoguanine are potent sources of replication errors in vivo. Biochemistry 2003, 42, 9257-9262. [CrossRef] [PubMed]

35. Henderson, P.T.; Neeley, W.L.; Delaney, J.C.; Gu, F.; Niles, J.C.; Hah, S.S.; Tannenbaum, S.R.; Essigmann, J.M. Urea lesion formation in DNA as a consequence of 7,8-dihydro-8-oxoguanine oxidation and hydrolysis provides a potent source of point mutations. Chem. Res. Toxicol. 2005, 18, 12-18. [CrossRef] [PubMed]

36. Yuan, B.; Wang, J.; Cao, H.; Sun, R.; Wang, Y. High-throughput analysis of the mutagenic and cytotoxic properties of DNA lesions by next-generation sequencing. Nucleic Acids Res. 2011, 39, 5945-5954. [CrossRef] [PubMed] 
37. You, C.; Swanson, A.L.; Dai, X.; Yuan, B.; Wang, J.; Wang, Y. Translesion synthesis of

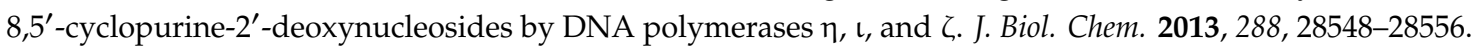
[CrossRef] [PubMed]

38. Yuan, B.; Jiang, Y.; Wang, Y.; Wang, Y. Efficient formation of the tandem thymine glycol/8-oxo-7,8-dihydroguanine lesion in isolated DNA and the mutagenic and cytotoxic properties of the tandem lesions in Escherichia coli cells. Chem. Res. Toxicol. 2010, 23, 11-19. [CrossRef] [PubMed]

39. Fedeles, B.I.; Freudenthal, B.D.; Yau, E.; Singh, V.; Chang, S.; Li, D.; Delaney, J.C.; Wilson, S.H.; Essigmann, J.M. Intrinsic mutagenic properties of 5-chlorocytosine: A mechanistic connection between chronic inflammation and cancer. Proc. Natl. Acad. Sci. USA 2015, 112, E4571-E4580. [CrossRef]

40. Kreutzer, D.A.; Essigmann, J.M. Oxidized, deaminated cytosines are a source of $\mathrm{C} \rightarrow \mathrm{T}$ transitions in vivo. Proc. Natl. Acad. Sci. USA 1998, 95, 3578-3582. [CrossRef] [PubMed]

41. Kroeger, K.M.; Jiang, Y.L.; Kow, Y.W.; Goodman, M.F.; Greenberg, M.M. Mutagenic effects of 2-deoxyribonolactone in Escherichia coli. An abasic lesion that disobeys the A-rule. Biochemistry 2004, 43, 6723-6733. [CrossRef] [PubMed]

42. Shrivastav, N.; Fedeles, B.I.; Li, D.; Delaney, J.C.; Frick, L.E.; Foti, J.J.; Walker, G.C.; Essigmann, J.M. A chemical genetics analysis of the roles of bypass polymerase DinB and DNA repair protein AlkB in processing $N^{2}$-alkylguanine lesions in vivo. PLoS ONE 2014, 9, e94716. [CrossRef] [PubMed]

43. Yuan, B.; You, C.; Andersen, N.; Jiang, Y.; Moriya, M.; O'Connor, T.R.; Wang, Y. The roles of DNA polymerases $\mathrm{K}$ and $\mathrm{\iota}$ in the error-free bypass of $\mathrm{N}^{2}$-carboxyalkyl-2'-deoxyguanosine lesions in mammalian cells. J. Biol. Chem. 2011, 286, 17503-17511. [CrossRef] [PubMed]

44. Yuan, B.; Cao, H.; Jiang, Y.; Hong, H.; Wang, Y. Efficient and accurate bypass of $N^{2}$-(1-carboxyethyl)-2'-deoxyguanosine by DinB DNA polymerase in vitro and in vivo. Proc. Natl. Acad. Sci. USA 2008, 105, 8679-8684. [CrossRef] [PubMed]

45. Delaney, J.C.; Essigmann, J.M. Context-dependent mutagenesis by DNA lesions. Chem. Biol. 1999, 6, 743-753. [CrossRef]

46. Delaney, J.C.; Essigmann, J.M. Effect of sequence context on $O^{6}$-methylguanine repair and replication in vivo. Biochemistry 2001, 40, 14968-14975. [CrossRef] [PubMed]

47. Wang, P.; Leng, J.; Wang, Y. DNA replication studies of $N$-nitroso compound-induced $\mathrm{O}^{6}$-alkyl-2'-deoxyguanosine lesions in Escherichia coli. J. Biol. Chem. 2019, 294, 3899-3908. [CrossRef] [PubMed]

48. Wu, J.; Wang, P.; Li, L.; Williams, N.L.; Ji, D.; Zahurancik, W.J.; You, C.; Wang, J.; Suo, Z.; Wang, Y. Replication studies of carboxymethylated DNA lesions in human cells. Nucleic Acids Res. 2017, 45, 7276-7284. [CrossRef] [PubMed]

49. Frick, L.E.; Delaney, J.C.; Wong, C.; Drennan, C.L.; Essigmann, J.M. Alleviation of $1, N^{6}$-ethanoadenine genotoxicity by the Escherichia coli adaptive response protein AlkB. Proc. Natl. Acad. Sci. USA 2007, 104, 755-760. [CrossRef] [PubMed]

50. Pollack, M.; Yang, I.-Y.; Kim, H.-Y.H.; Blair, I.A.; Moriya, M. Translesion DNA Synthesis across the heptanone-etheno-2'-deoxycytidine adduct in cells. Chem. Res. Toxicol. 2006, 19, 1074-1079. [CrossRef] [PubMed]

51. Chang, S.-C.; Seneviratne, U.I.; Wu, J.; Tretyakova, N.; Essigmann, J.M. 1,3-Butadiene-Induced Adenine DNA Adducts Are Genotoxic but Only Weakly Mutagenic When Replicated in Escherichia coli of Various Repair and Replication Backgrounds. Chem. Res. Toxicol. 2017, 30, 1230-1239. [CrossRef] [PubMed]

52. Wu, J.; Wang, P.; Li, L.; You, C.; Wang, Y. Cytotoxic and mutagenic properties of minor-groove $\mathrm{O}^{2}$-alkylthymidine lesions in human cells. J. Biol. Chem. 2018, 293, 8638-8644. [CrossRef] [PubMed]

53. Weerasooriya, S.; Jasti, V.P.; Bose, A.; Spratt, T.E.; Basu, A.K. Roles of translesion synthesis DNA polymerases in the potent mutagenicity of tobacco-specific nitrosamine-derived $O^{2}$-alkylthymidines in human cells. $D N A$ Repair (Amst.) 2015, 35, 63-70. [CrossRef] [PubMed]

54. Jasti, V.P.; Spratt, T.E.; Basu, A.K. Tobacco-specific nitrosamine-derived $O^{2}$-alkylthymidines are potent mutagenic lesions in SOS-induced Escherichia coli. Chem. Res. Toxicol. 2011, 24, 1833-1835. [CrossRef] [PubMed]

55. Zhai, Q.; Wang, P.; Wang, Y. Cytotoxic and mutagenic properties of regioisomeric $\mathrm{O}^{2}-$, N3- and $\mathrm{O}^{4}$-ethylthymidines in bacterial cells. Carcinogenesis 2014, 35, 2002-2006. [CrossRef] [PubMed] 
56. Wu, J.; Li, L.; Wang, P.; You, C.; Williams, N.L.; Wang, Y. Translesion synthesis of $O^{4}$-alkylthymidine lesions in human cells. Nucleic Acids Res. 2016, 44, 9256-9265.

57. Li, D.; Fedeles, B.I.; Singh, V.; Peng, C.S.; Silvestre, K.J.; Simi, A.K.; Simpson, J.H.; Tokmakoff, A.; Essigmann, J.M. Tautomerism provides a molecular explanation for the mutagenic properties of the anti-HIV nucleoside 5-aza-5,6-dihydro-2'-deoxycytidine. Proc. Natl. Acad. Sci. USA 2014, 111, E3252-E3259. [CrossRef]

58. Ji, D.; You, C.; Wang, P.; Wang, Y. Effects of tet-induced oxidation products of 5-methylcytosine on DNA replication in mammalian cells. Chem. Res. Toxicol. 2014, 27, 1304-1309. [CrossRef]

59. Xing, X.-W.; Liu, Y.-L.; Vargas, M.; Wang, Y.; Feng, Y.-Q.; Zhou, X.; Yuan, B.-F. Mutagenic and cytotoxic properties of oxidation products of 5-methylcytosine revealed by next-generation sequencing. PLoS ONE 2013, 8, e72993. [CrossRef]

60. Ji, D.; Wang, Y. Facile enzymatic synthesis of base J-containing oligodeoxyribonucleotides and an analysis of the impact of base J on DNA replication in cells. PLoS ONE 2014, 9, e103335. [CrossRef]

61. Wu, J.; Wang, P.; Wang, Y. Cytotoxic and mutagenic properties of alkyl phosphotriester lesions in Escherichia coli cells. Nucleic Acids Res. 2018, 46, 4013-4021. [CrossRef] [PubMed]

62. Bose, A.; Surugihalli, C.; Pande, P.; Champeil, E.; Basu, A.K. Comparative Error-Free and Error-Prone Translesion Synthesis of $N^{2}-2^{\prime}$-Deoxyguanosine Adducts Formed by Mitomycin C and Its Metabolite, 2,7-Diaminomitosene, in Human Cells. Chem. Res. Toxicol. 2016, 29, 933-939. [CrossRef] [PubMed]

63. Attaluri, S.; Bonala, R.R.; Yang, I.-Y.; Lukin, M.A.; Wen, Y.; Grollman, A.P.; Moriya, M.; Iden, C.R.; Johnson, F. DNA adducts of aristolochic acid II: Total synthesis and site-specific mutagenesis studies in mammalian cells. Nucleic Acids Res. 2010, 38, 339-352. [CrossRef] [PubMed]

64. Bailey, E.A.; Iyer, R.S.; Stone, M.P.; Harris, T.M.; Essigmann, J.M. Mutational properties of the primary aflatoxin B1-DNA adduct. Proc. Natl. Acad. Sci. USA 1996, 93, 1535-1539. [CrossRef] [PubMed]

65. Smela, M.E.; Hamm, M.L.; Henderson, P.T.; Harris, C.M.; Harris, T.M.; Essigmann, J.M. The aflatoxin B1 formamidopyrimidine adduct plays a major role in causing the types of mutations observed in human hepatocellular carcinoma. Proc. Natl. Acad. Sci. USA 2002, 99, 6655-6660. [CrossRef] [PubMed]

66. Watt, D.L.; Utzat, C.D.; Hilario, P.; Basu, A.K. Mutagenicity of the 1-nitropyrene-DNA adduct N-(deoxyguanosin-8-yl)-1-aminopyrene in mammalian cells. Chem. Res. Toxicol. 2007, 20, 1658-1664. [CrossRef] [PubMed]

67. Hashimoto, K.; Bonala, R.; Johnson, F.; Grollman, A.P.; Moriya, M. Y-family DNA polymerase-independent gap-filling translesion synthesis across aristolochic acid-derived adenine adducts in mouse cells. DNA Repair (Amst.) 2016, 46, 55-60. [CrossRef]

68. Hashimoto, K.; Cho, Y.; Yang, I.-Y.; Akagi, J.; Ohashi, E.; Tateishi, S.; de Wind, N.; Hanaoka, F.; Ohmori, H.; Moriya, M. The Vital Role of Polymerase $\zeta$ and REV1 in Mutagenic, but Not Correct, DNA Synthesis across Benzo $[a]$ pyrene-dG and Recruitment of Polymerase $\zeta$ by REV1 to Replication-stalled Site. J. Biol. Chem. 2012, 287, 9613-9622. [CrossRef] [PubMed]

69. Liu, X.; Lao, Y.; Yang, I.-Y.; Hecht, S.S.; Moriya, M. Replication-coupled repair of crotonaldehyde/ acetaldehyde-induced guanine-guanine interstrand cross-links and their mutagenicity. Biochemistry 2006, 45, 12898-12905. [CrossRef]

70. Price, N.E.; Li, L.; Gates, K.S.; Wang, Y. Replication and repair of a reduced 2'-deoxyguanosine-abasic site interstrand cross-link in human cells. Nucleic Acids Res. 2017, 45, 6486-6493. [CrossRef]

71. Naser, L.J.; Pinto, A.L.; Lippard, S.J.; Essigmann, J.M. Chemical and biological studies of the major DNA adduct of cis-diamminedichloroplatinum(II), cis-[Pt( $\left.\mathrm{NH}_{3}\right)_{2}(\mathrm{~d}(\mathrm{GpG})]$, built into a specific site in a viral genome. Biochemistry 1988, 27, 4357-4367. [CrossRef] [PubMed]

72. Yarema, K.J.; Lippard, S.J.; Essigmann, J.M. Mutagenic and genotoxic effects of DNA adducts formed by the anticancer drug cis-diamminedichloroplatinum(II). Nucleic Acids Res. 1995, 23, 4066-4072. [CrossRef] [PubMed]

73. Ji, S.; Fu, I.; Naldiga, S.; Shao, H.; Basu, A.K.; Broyde, S.; Tretyakova, N.Y. 5-Formylcytosine mediated DNA-protein cross-links block DNA replication and induce mutations in human cells. Nucleic Acids Res. 2018, 46, 6455-6469. [CrossRef] [PubMed]

74. Kim, T.W.; Delaney, J.C.; Essigmann, J.M.; Kool, E.T. Probing the active site tightness of DNA polymerase in subangstrom increments. Proc. Natl. Acad. Sci. USA 2005, 102, 15803-15808. [CrossRef] [PubMed] 
75. Delaney, J.C.; Gao, J.; Liu, H.; Shrivastav, N.; Essigmann, J.M.; Kool, E.T. Efficient replication bypass of size-expanded DNA base pairs in bacterial cells. Angew. Chem. Int. Ed. Engl. 2009, 48, 4524-4527. [CrossRef] [PubMed]

76. Amato, N.J.; Zhai, Q.; Navarro, D.C.; Niedernhofer, L.J.; Wang, Y. In vivo detection and replication studies of $\alpha$-anomeric lesions of 2'-deoxyribonucleosides. Nucleic Acids Res. 2015, 43, 8314-8324. [CrossRef] [PubMed]

77. Wang, P.; Amato, N.J.; Wang, Y. Cytotoxic and Mutagenic Properties of C3'-Epimeric Lesions of 2'-Deoxyribonucleosides in Escherichia coli Cells. Biochemistry 2017, 56, 3725-3732. [CrossRef]

78. Yuan, B.; Wang, Y. Mutagenic and cytotoxic properties of 6-thioguanine, $S^{6}$-methylthioguanine, and guanine- $S^{6}$-sulfonic acid. J. Biol. Chem. 2008, 283, 23665-23670. [CrossRef]

79. Yuan, B.; O'Connor, T.R.; Wang, Y. 6-Thioguanine and $S^{6}$-methylthioguanine are mutagenic in human cells. ACS Chem. Biol. 2010, 5, 1021-1027. [CrossRef]

80. Reuven, N.B.; Tomer, G.; Livneh, Z. The mutagenesis proteins UmuD' and UmuC prevent lethal frameshifts while increasing base substitution mutations. Mol. Cell 1998, 2, 191-199. [CrossRef]

81. Stein, S.; Lao, Y.; Yang, I.-Y.; Hecht, S.S.; Moriya, M. Genotoxicity of acetaldehyde- and crotonaldehyde-induced 1, $N^{2}$-propanodeoxyguanosine DNA adducts in human cells. Mutat. Res. 2006, 608, 1-7. [CrossRef]

82. Zhai, Q.; Wang, P.; Cai, Q.; Wang, Y. Syntheses and characterizations of the in vivo replicative bypass and mutagenic properties of the minor-groove $O^{2}$-alkylthymidine lesions. Nucleic Acids Res. 2014, 42, 10529-10537. [CrossRef]

83. Fedeles, B.I.; Essigmann, J.M. Impact of DNA lesion repair, replication and formation on the mutational spectra of environmental carcinogens: Aflatoxin B1 as a case study. DNA Repair (Amst.) 2018, 71, 12-22. [CrossRef]

84. Chawanthayatham, S.; Valentine, C.C.; Fedeles, B.I.; Fox, E.J.; Loeb, L.A.; Levine, S.S.; Slocum, S.L.; Wogan, G.N.; Croy, R.G.; Essigmann, J.M. Mutational spectra of aflatoxin B1 in vivo establish biomarkers of exposure for human hepatocellular carcinoma. Proc. Natl. Acad. Sci. USA 2017, 114, E3101-E3109. [CrossRef]

85. Alexandrov, L.B.; Stratton, M.R. Mutational signatures: The patterns of somatic mutations hidden in cancer genomes. Curr. Opin. Genet. Dev. 2014, 24, 52-60. [CrossRef]

86. Stratton, M.R. Exploring the genomes of cancer cells: Progress and promise. Science 2011, 331, $1553-1558$. [CrossRef]

87. Kim, M.Y.; Zhou, X.; Delaney, J.C.; Taghizadeh, K.; Dedon, P.C.; Essigmann, J.M.; Wogan, G.N. AlkB influences the chloroacetaldehyde-induced mutation spectra and toxicity in the pSP189 supF shuttle vector. Chem. Res. Toxicol. 2007, 20, 1075-1083. 